\title{
O DIABETES MELLITUS INDUZ ALTERAÇÕES EPIGENÉTICAS NO GENE SLC2A4 EM MÚSCULO ESQUELÉTICO QUE SE RELACIONAM COM A REPRESSÃO DO GENE, E QUE PODEM SER REVERTIDAS PELA INSULINOTERAPIA OU PELO RESVERATROL
}

Tese apresentada ao Programa de PósGraduação em Fisiologia Humana do Instituto de Ciências Biomédicas da Universidade de São Paulo, para a obtenção do Título de Doutor em Ciências.

Área de concentração: Fisiologia Humana

Orientador: Prof. Dr. Ubiratan Fabres Machado

Versão original 


\section{RESUMO}

YONAMINE, C. Y. O Diabetes Mellitus induz alterações epigenéticas no gene slc2a4 em músculo esquelético que se relacionam com a repressão do gene, e que podem ser revertidas pela insulinoterapia ou pelo resveratrol. 2017. 135 f., Tese (Doutorado em Fisiologia Humana) - Instituto de Ciências Biomédicas, Universidade de São Paulo, São Paulo, 2017.

A principal característica do diabetes mellitus (DM) é a perda da homeostasia glicêmica. Nesse processo, o músculo esquelético desempenha papel chave, visto que é responsável por aproximadamente $75 \%$ do clareamento da glicose extracelular; e, para tal, a adequada expressão do transportador de glicose GLUT4 (codificado pelo gene Slc2a4) é fundamental. Tanto no DM1 como no DM2 observa-se uma redução da expressão do gene $S l c 2 a 4$, o que, junto com outros mecanismos fisiopatológicos, contribui para a perda do controle glicêmico. A investigação de mecanismos que regulem a expressão desse gene pode servir de base para o desenvolvimento de estratégias preventivas e/ou terapêuticas para o DM. Regulações epigenéticas do Slc2a4, como a acetilação e a trimetilação de histona H3 (H3KAc e H3K9me3, respectivamente), nunca foram investigadas no DM; e o resveratrol, sugerido como sensibilizador da insulina, poderia modular essas regulações, pois é um ativador da desacetilase sirtuína 1 (SIRT1). Assim, o presente estudo teve por objetivo avaliar em ratos DM1 (por estreptozotocina) tratados com insulina e em camundongos DM2 (por glutamato monossódico) o efeito do tratamento com resveratrol sobre a homeostasia glicêmica, a expressão de Slc2a4/GLUT4 em músculo esquelético, a regulação epigenética do Slc2a4, e a possível participação da SIRT1. Observou-se que o tratamento crônico com resveratrol melhorou a homeostasia glicêmica no DM1 tratado com insulina e, isoladamente, no DM2. Apesar disso, a expressão do gene Slc2a4 no músculo esquelético foi modulada pelo resveratrol apenas no DM2, indicando que no DM1 tratado com insulina outros territórios participaram da melhora do controle glicêmico. Em todas as condições experimentais, a metilação de citosinas em sítios CCGG do promotor do gene Slc2a 4 mostrou-se pouco alterada, sem contribuir para explicar as alterações de expressão de Slc2a4. Por outro lado, ensaios de imunoprecipitação de cromatina evidenciaram importantes alterações na modulação pós-traducional (PTM) de histonas H3. No DM1, houve redução de H3KAc e aumento de H3K9me3 em região promotora estimuladora da transcrição do gene $S l c 2 a 4$, e ambas as alterações foram revertidas com a insulinoterapia. Esses resultados estão em pleno acordo com as regulações de expressão do $S l c 2 a 4$ observadas. No DM1 tratado com insulina a adição do resverarol não alterou a expressão do Slc2a4; e, portanto, regulações epigenéticas não foram investigadas nessa condição. No DM2 observouse redução no conteúdo de $\mathrm{H} 3 \mathrm{~K} 9 \mathrm{me} 3$ no promotor do Slc2a4, e isso reverteu após tratamento com resveratrol; efeitos que podem explicar as alterações da expressão do gene Slc2a4 observadas. Adicionalmente, verificou-se que o conteúdo de SIRT1 nuclear: 1) aumentou nos animais DM1 e reduziu com a insulinoterapia, e 2) aumentou nos animais DM2 tratados com resveratrol, indicando que a maquinaria epigenética reguladora da expressão do gene Slc2a 4 é, pelo menos parcialmente, regulada pela SIRT1. Em suma, o presente estudo revela a ocorrência de regulações epigenéticas no gene Slc $2 a 4$ em músculo de animais diabéticos, com destaque para as PTMs de histona H3; além disso, mostra que o tratamento com resveratrol modula algumas dessas alterações, melhorando o controle glicêmico. Esses resultados apoiam o resveratrol como um sensibilizador da insulina, e constroem bases para o desenvolvimento de terapias epigenéticas para o DM.

Palavras-chave: diabetes mellitus. resveratrol. epigenética. acetilação de histona H3. trimetilação de histona H3. SIRT1. 


\begin{abstract}
YONAMINE, C. Y. Diabetes Mellitus induces epigenetic alterations in the slc2a4 gene in skeletal muscle that relate to gene repression and can be reversed by insulinotherapy or resveratrol. 2017. 135 p., Ph.D. thesis (Human Physiology) - Instituto de Ciências Biomédicas, Universidade de São Paulo, São Paulo, 2017.
\end{abstract}

The main characteristic of diabetes mellitus (DM) is the loss of glycemic homeostasis. In this process, skeletal muscle plays a key role, since it accounts for approximately $75 \%$ of glucose uptake and, for this, the maintenance expression of the GLUT4 glucose transporter (encoded by the Slc2a4 gene) is fundamental. In both DM1 and DM2, is observed a reduction in the expression of the Slc2a4 gene, which, along with other pathophysiological mechanisms, contributes to the loss of glycemic control. The investigation of mechanisms that regulate the expression of this gene can serve as a basis for the development of preventive and/or therapeutic strategies for DM. Epigenetic regulations of Slc2a4, such as histone H3 acetylation and trimethylation (H3KAc and $\mathrm{H} 3 \mathrm{~K} 9 \mathrm{me} 3$, respectively), have never been investigated in DM; and resveratrol, suggested as an insulin sensitizer, could modulate these regulations, as it is an activator of the deacetylase sirtuin 1 (SIRT1). Thus, the present study aimed to evaluate in DM1 rats (by streptozotocin) treated with insulin and in DM2 mice (by monosodium glutamate) the effect of resveratrol treatment on glycemic homeostasis, Slc2a4 / GLUT4 expression in skeletal muscle, the epigenetic regulation of Slc2a4, and the possible participation of SIRT1. It was observed that chronic treatment with resveratrol improved glycemic homeostasis in insulintreated DM1 and, alone, in DM2. Despite this, the expression of the Slc2a4 gene in skeletal muscle was modulated by resveratrol only in DM2, indicating that in DM1 treated with insulin other territories participated in the improvement of glycemic control. In all experimental conditions, methylation of cytosines at CCGG sites located in Slc2a 4 gene promoter region has been shown to be slightly altered, without contributing to explain the changes in Slc2a4 expression. On the other hand, chromatin immunoprecipitation assays evinced important changes in post-translational modulation (PTM) of histone H3. In DM1, there was a reduction of $\mathrm{H} 3 \mathrm{KAc}$ and an increase of $\mathrm{H} 3 \mathrm{~K} 9 \mathrm{me} 3$ at stimulatory segment of transcription in promoter region of Slc $2 a 4$ gene, and both alterations were reversed with the insulin therapy. These results are in full agreement with the observed Slc2a4 expression settings. In DM1 treated with insulin the addition of resveratrol did not alter the expression of Slc2a4; and, therefore, epigenetic adjustments were not investigated in this condition. In DM2 a reduction in the content of H3K9me3 in the Slc2a4 promoter was observed, and this reversed after treatment with resveratrol; effects that may explain changes in Slc2a4 gene expression observed. Additionally, the nuclear SIRT1 content: 1) increased in the DM1 animals and reduced with insulin therapy, and 2) increased in the DM2 animals treated with resveratrol, indicating that the epigenetic machinery regulating the expression of the Slc2a4 gene is, at least partially, regulated by SIRT1. In summary, the present study reveals the occurrence of epigenetic regulation in the Slc2a4 gene in muscle of diabetic animals, with emphasis on histone H3 PTMs; furthermore, it shows that resveratrol treatment modulates some of these changes, improving glycemic control. These results support resveratrol as an insulin sensitizer, and build bases for the development of epigenetic therapies for DM.

Keywords: Diabetes mellitus. resveratrol. Slc2a4. GLUT4. epigenetic. Histone H3 methylation. Histone H3 acetylation. SIRT1. 


\section{INTRODUÇÃO}

O diabetes mellitus (DM) é uma doença metabólica caracterizada principalmente pela perda da homeostasia glicêmica. Conforme a etiologia, o DM pode ser classificado em tipos 1 e 2 (DM1 e DM2). O DM1 tem como causa primária a destruição autoimune das células B das ilhotas pancreáticas, acarretando ausência de produção e secreção de insulina; enquanto a causa primária do DM2 é a resistência periférica à ação da insulina. Independentemente da causa do DM, a hiperglicemia é a principal característica fisiopatológica, e é responsável direta ou indiretamente pelo aparecimento de diversas complicações crônicas que acometem vários territórios alvos (COLEMAN et al., 2015).

Conforme os últimos dados publicados pela Federação Internacional do Diabetes, estima-se que no Brasil haja aproximadamente 14 milhões de indivíduos diabéticos e, em 2040, esse número subirá para aproximadamente 23 milhões. Esses dados per se contextualizam a importância epidemiológica de estudar o diabetes no intuito de reduzir o avanço de sua incidência.

A compreensão do DM exige explorar as consequências que a ausência do hormônio insulina ou a deficiência de sua ação provocam na homeostasia glicêmica. A insulina atua por meio da interação com seu receptor do tipo tirosina cinase, localizado na membrana plasmática, ativando vias de sinalização intracelulares, como a PI3K/AKT que estimula a translocação de vesículas contendo a isoforma 4 dos transportadores de glicose (GLUT4) do citosol para a membrana plasmática em músculo esquelético e cardíaco, e em tecido adiposo branco e marrom (ZIERATH; KROOK; WALLBERG-HENRIKSSON, 2000). Além disso, a ação da insulina é capaz de estimular a maquinaria de expressão do gene Slc2a4 (solute carrier family 2 member 4), responsável pela codificação da proteína GLUT4 (MORAES et al., 2014). Importante salientar que a manutenção adequada do conteúdo proteico de GLUT4 nas vesículas é crucial para o processo de captação de glicose, uma vez que determina a quantidade absoluta de transportadores translocados à membrana plasmática (CORREAA-GIANNELLA; MACHADO, 2013). Essas informações contextualizam os fundamentos básicos da captação de glicose pelo músculo esquelético, cuja alteração participa da fisiopatologia do DM. Com base nisso, muitos estudos focaram em aprofundar os conhecimentos acerca dos mecanismos regulatórios da expressão do gene Slc2a4 nesse território (CORRÊA-GIANNELLA; MACHADO, 2013).

O músculo esquelético é responsável, em condições fisiológicas, por aproximadamente $75 \%$ do total de clareamento de glicose da circulação sanguínea (KOISTINEN; ZIERATH, 2002; ZIERATH et al., 2000). No DM, observa-se uma redução na captação de glicose, que 
envolve menor expressão/translocação de GLUT4, principalmente no músculo esquelético, contribuindo para a sustentação da hiperglicemia. A manutenção de níveis adequados de expressão de GLUT4 no músculo esquelético é, portanto, elemento chave no controle da homeostasia glicêmica, incluindo prevenção e tratamento da resistência à insulina, condição presente no DM (CORRÊA-GIANNELLA; MACHADO, 2013; OKAMOTO et al., 2011).

O desenvolvimento de técnicas de manipulação genética permitiu a caracterização das consequências diretas da superexpressão ou repressão do gene Slc2a4 sobre a homeostasia glicêmica. Tsao e colaboradores (1999) demonstraram que camundongos com deleção heterozigótica do gene $S l c 2 a 4$ em músculo esquelético desenvolvem um quadro de resistência à ação da insulina, enquanto a normalização da expressão nesses mesmos animais recupera a sensibilidade normal da ação à insulina, provando que a expressão do gene Slc2a4 é decisiva para a manutenção da captação de glicose pelo músculo, e consequentemente da homeostasia glicêmica. Adicionalmente, em camundongos diabéticos $d b / d b$, que apresentam resistência à insulina, a superexpressão do gene Slc2a4 é capaz de normalizar a sensibilidade à insulina e a tolerância à sobrecarga de glicose (BROZINICK et al., 2001; GIBBS et al., 1995).

O desenvolvimento de técnicas para medir a atividade de regiões promotoras de genes foi crucial para o entendimento do processo de transcrição do gene Slc2a4, e permitiu a identificação de inúmeros fatores transcricionais que regulam a sua expressão (OLSON; KNIGHT, 2003). A caracterização desses fatores e de seus modos de atuação foram essenciais para a compreensão detalhada da regulação da expressão do gene $S l c 2 a 4$, permitindo o aprimoramento de estratégias que poderão contribuir para o controle da homeostasia glicêmica no DM (ZORZANO; PALACÍN; GUMÀ, 2005).

Analisando os fatores transcricionais participantes da regulação da expressão do gene Slc2a4 no músculo esquelético, observa-se que a maioria deles são ativadores, como o MEF2 (myocyte-specific enhancer factor 2), TR (thyroid hormone receptor), MyoD (Myoblast determination protein 1), HIF1A (hypoxia inducible factor 1 alpha), e SP1 (Transcription factor Sp1) entre outros (RICHARDSON; PESSIN,1993; SANTALUCIA et al., 2001; SILVA et al., 2005). É interessante que a expressão de alguns desses fatores e a sua afinidade de interação ao promotor de gene Slc2a4 são primorosamente reguladas pela ação da insulina (MORAES et al., 2014). No DM, já foi descrito que a ligação do MEF2 na região promotora do gene Slc2a4 está reduzida, concomitantemente à sua expressão, e o tratamento com insulina é capaz de reverter a expressão do $S l c 2 a 4$ por aumentar a ligação do MEF2 à região promotora do Slc2a4 (THAI et al., 1998). 
Por outro lado, poucos fatores transcricionais foram descritos como inibidores da expressão do gene Slc2a4. O PPARG (peroxisome proliferator-activated receptor gama) é um repressor da transcrição que age na sua forma não-ligada, isto é, na ausência de agonistas, como as glitasonas, que na verdade são ligantes indutores de desrepressão do gene Slc2a4 (KARNIELLI; ARMONI, 2008). De suma importância foi a recente demonstração de que o NFKB (nuclear factor kappa-B), um potente mediador de efeitos pró-inflamatórios, é capaz de reprimir a expressão do gene Slc2a4, ligando-se em duas sequências da região promotora desse gene (FURUYA et al., 2013).

O NF-1 (Nuclear fator 1) e o O/E-1 (Transcription factor COE1) são dois fatores transcricionais relacionados à repressão do gene $\operatorname{Slc} 2 a 4$, mas que são muito pouco mencionados na literatura. A ação deles como repressores foi demonstrada em linhagens celulares provenientes de adipócitos de camundongos (3T3-L1) (COOKE; LANE, 1999; DOWELL; COOKE, 2002; MIURA et al., 2004). No entanto, não há evidências até hoje a respeito da ação deles em modelos celulares provenientes de músculo e menos ainda se sabe sobre a participação deles em modelos in vivo de DM.

Apesar dos grandes avanços na compreensão da regulação da expressão gênica do Slc2a4, muito ainda há que se aprender. Nesse sentido, uma nova e promissora área de conhecimento envolve a epigenética, visto que há fortes evidências de que alterações epigenéticas participam da fisiopatologia do DM (KWAK; PARK, 2016). A atuação de mecanismos epigenéticos sobre a maquinaria de expressão do gene Slc2a4 em músculo esquelético é muito pouco conhecida, sobretudo na condição do DM, carecendo, portanto de investigações mais detalhadas.

A epigenética não possui uma definição exata, mas pode ser relacionada a um ramo da ciência que estuda a interação entre fatores ambientais e gênicos, que até podem ser herdados, mas que não envolvem modificações na sequência de nucleotídeos do DNA, e que se refletem na regulação da expressão gênica, replicação e diferenciação celular (JAENISCH; BIRD, 2003). Estudos evidenciam que a maquinaria epigenética é crucial na regulação da expressão de genes, provavelmente interferindo na atividade de ligação de fatores transcricionais (QUANTE; BIRD, 2016). Importante destacar que as alterações epigenéticas podem ser transmitidas para a próxima geração tanto por herança mitótica, divisão celular, quanto por herança meiótica, isto é, ao longo de gerações (BIRD, 2007).

Há evidências de que os mecanismos epigenéticos participam diretamente na predisposição e no desenvolvimento de doenças metabólicas, sendo que no DM já foram descritas diversas alterações epigenéticas afetando diretamente o padrão de expressão de genes 
relacionados ao metabolismo em diferentes territórios do organismo (AL-HADDAD et al., 2016; KIRCHNER et al., 2013; STEFAN et al., 2014). Com base nisso, a investigação de mecanismos epigenéticos relacionados à expressão do gene $S l c 2 a 4$ contribuirá para evoluir o conhecimento que temos até o momento acerca da regulação desse gene no DM.

A metilação do DNA, mecanismo epigenético mais estudado, consiste na adição de grupamento metil $\left(\mathrm{CH}_{3}\right)$ no carbono localizado na posição $5^{`}$ do anel pirimidínico de citosinas situadas principalmente em dinucleotídeos chamados $\mathrm{CpG}$, sendo que a letra $\mathrm{p}$ representa a ligação fosfato entre os nucleosídeos citosina e guanina (DEATON; BIRD, 2011). Essa reação química é catalisada por enzimas conhecidas como DNA metiltransferases (DNMT). O grupamento metil provém da conversão da S-adenosilmetionina (SAM) em Sadenosilhomocisteína (SAH). As DNMTs conhecidas são a DNMT1 que é responsável pela manutenção da metilação das citosinas durante o processo de replicação celular, sendo também a primeira isoforma descoberta (BESTOR et al., 1988) e as DNMT3a/b que são responsáveis pela metilação de novo. Existe também a DNMT2, mas pouco se sabe sobre suas ações (ROBERTSON, 2001).

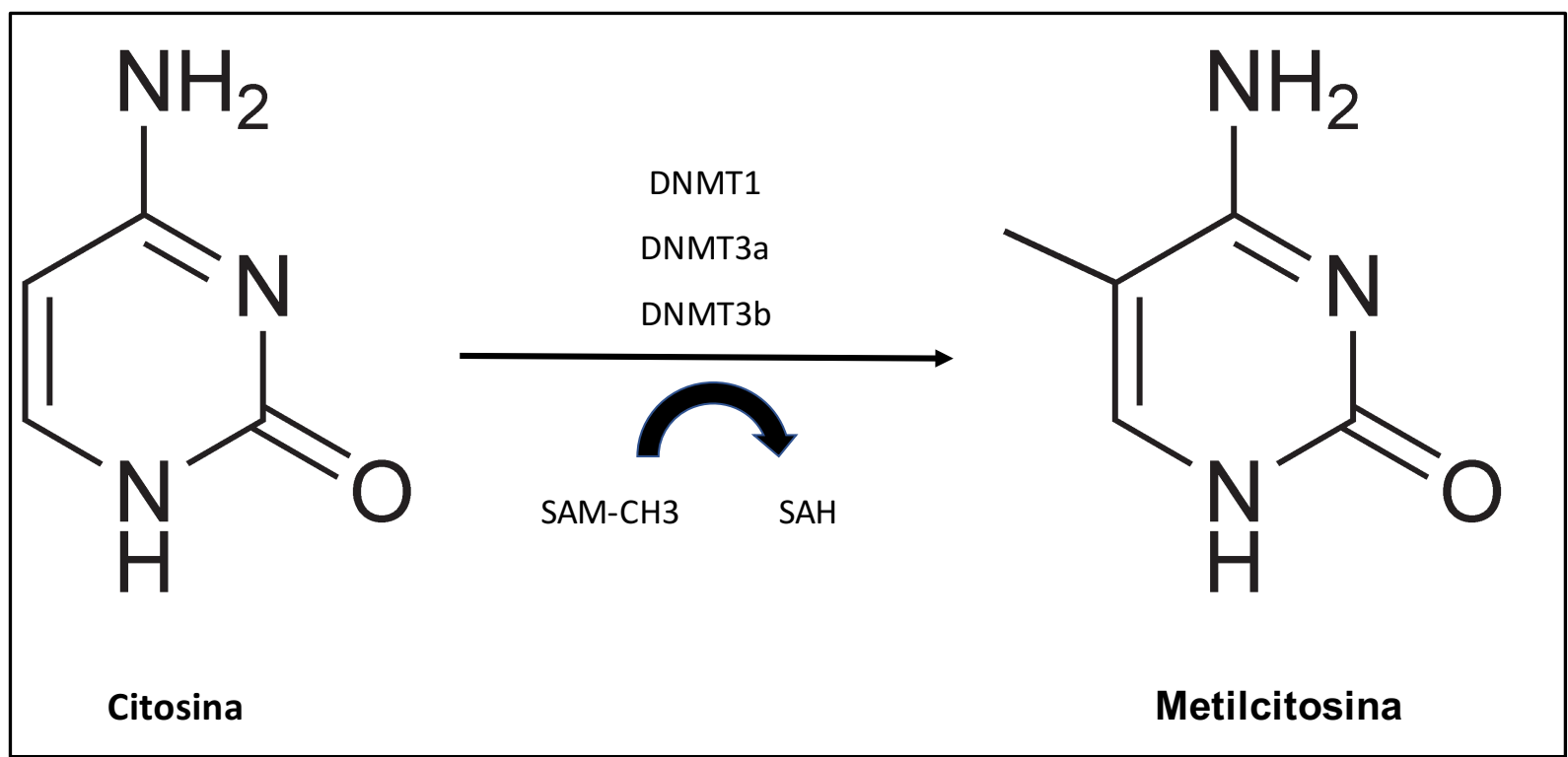

Figura 1 - Representação esquemática da reação de metilação da citosina envolvendo a doação do grupamento metil da S-adenosilmetionina (SAM) catalisada pelas DNMT1, 3a ou 3b.

Recentemente, Tahiliani e colaboradores (2009) identificaram enzimas denominadas metilcitosina dioxigenases, mais conhecidas como TET (Ten eleven translocation). Existem três isoformas caracterizadas (TET1, TET2 e TET3) e todas elas são capazes de oxidar as citosinas metiladas, convertendo-as em produtos intermediários do processo de desmetilação 
do DNA, que inclui a 5-hidroximetilcitosina, a 5-formilcitosina e a 5-carboxilcitosina (RASMUSSEN; HELIN, 2016).

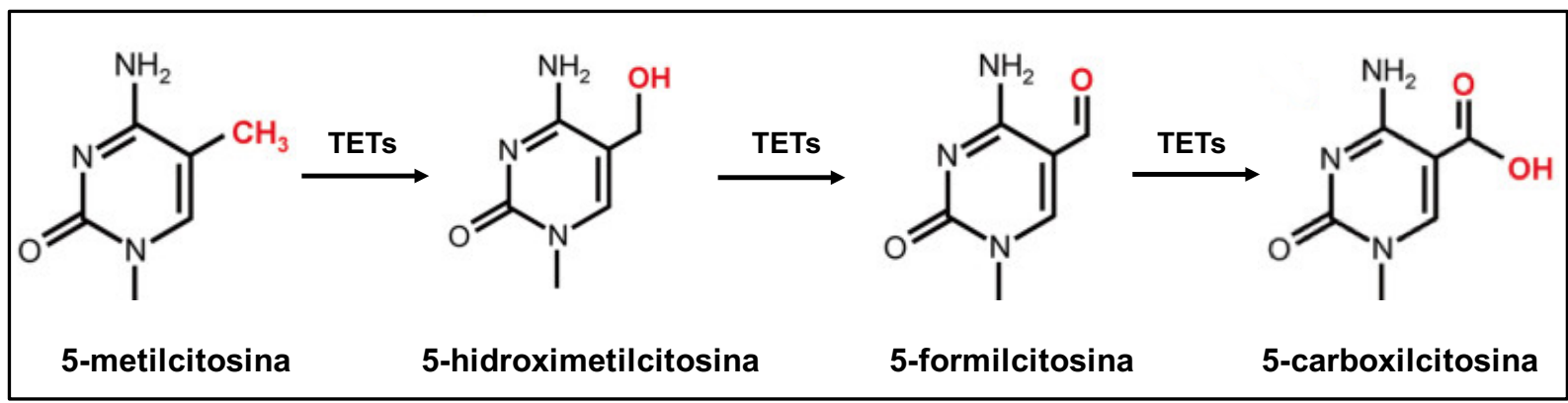

Figura 2 - Representação esquemática das fórmulas químicas estruturais dos intermediários formados ao longo do processo de desmetilação do DNA envolvendo reações de oxidação catalisada pelas enzimas TET.

Interessante notar que na estrutura química molecular de todas as TETs existem domínios de ligação para $\mathrm{Fe}^{2+}$ e 2-oxoglutarato, dado que sugere que a ação dessas enzimas pode ser regulada pela dieta e por produtos do metabolismo, e explica a reversibilidade e a dinamicidade da metilação/desmetilação do DNA (RASMUSSEN; HELIN, 2016). De fato, nesse sentido, Barrès e colaboradores (2012) verificaram, em músculo esquelético exercitado agudamente, alterações no grau de metilação principalmente em genes diretamente envolvidos no metabolismo oxidativo como PPARGC1A, PDK4 e PPARD.

Interessante que nos últimos anos diversas mutações genéticas nas enzimas DNMT e TET foram identificadas em modelos de câncer (HAMIDI; SINGH; CHEN, 2015), dados que fortalecem o papel delas na manutenção dos níveis adequados de metilação do DNA, e que sugerem suas participações na fisiopatologia de inúmeras doenças, incluindo o DM.

Considerando os dinucleotídeos $\mathrm{CpG}$ num contexto mais amplo, estima-se que correspondam à aproximadamente $25 \%$ da sequência genômica de mamíferos e podem ou não estarem localizadas em regiões denominadas como ilhas (CGi), que constituem de forma genérica regiões do DNA que apresentam elevada frequência de $\mathrm{C}+\mathrm{G}(\mathrm{HAN}$; ZHAO, 2009). Estima-se que, em mamíferos, apenas aproximadamente $1 \%$ do genoma seja constituído por CGi, no entanto, cerca de 60-70\% dos genes possuem ao menos uma CGi na região promotora, o que sugere a crucial importância da metilação do DNA na regulação da transcrição gênica (ILLINGWORTH; BIRD, 2009; WEBER et al., 2007). Ainda, as citosinas podem sofrer metilação fora do contexto de $\mathrm{CG}$, mas poucos estudos até o momento investigaram profundamente as implicações funcionais dessas modificações (PATIL; WARD; HESSON, 2014). 
Devido ao importante papel da metilação no DNA sobre a regulação da transcrição, alguns autores sugeriram distintos critérios de classificação e identificação de CGis (ZHAO; HAN, 2009). O primeiro critério, mais antigo, fundamenta-se em três parâmetros: 1) tamanho da sequência; 2) conteúdo GC dado em porcentagem; 3) razão $\mathrm{CpG}$ observado/CpG esperado. Os primeiros autores que determinaram esses parâmetros de classificação de CGi foram Gardiner-Garden e Frommer (1987) e, mais tarde, Takai e Jones (2001) revisaram e aprimoraram esses parâmetros. Já o segundo critério fundamenta-se na significância estatística, a partir da identificação e frequência de dinucleotídeos $\mathrm{CpG}$, em determinado fragmento da sequência do DNA (ZHAO; HAN, 2009). O CpGcluster e o CG Cluster são os algoritmos mais conhecidos para essa análise. Os detalhes técnicos de cada um dos principais algoritmos estão apresentados na tabela abaixo.

Tabela 1 - Detalhes dos parâmetros dos principais algoritmos de identificação de ilhas CpG.

\begin{tabular}{cc}
\hline & Parâmetros \\
\hline Gardiner-Garden e Frommer (1987) & $>200 \mathrm{pb},>50 \% \mathrm{GC}$, ObsCpG/ExpCpG $>0.60$ \\
Takai e Jones (2002) & $\geq 500 \mathrm{pb}, \geq 55 \% \mathrm{GC}$, ObsCpG/ExpCpG $\geq 0.65$ \\
CpGPRod & $>500 \mathrm{pb}, \mathrm{GC}>50 \%$, ObsCpG/ExpCpG $>0.60$ \\
CpGcluster & Agrupamento de CpGs separados por distância \\
& mediana com significância de P $<10^{-5}$ \\
CG Cluster & Humano $\geq 27$ CpGs em fragmento de DNA com \\
& 6531 pb Camundongos $\geq 24$ CpGs em fragmento de \\
& DNA com 6585 pb
\end{tabular}

Do ponto de vista funcional, a metilação no DNA pode recrutar proteínas e formar complexos capazes de regular o quanto os fatores transcricionais podem interagir com o DNA, e afetar assim o grau de expressão dos genes (JAENISCH; BIRD, 2003). Em geral, a hipermetilação da região promotora está relacionada com a repressão da expressão gênica, enquanto a hipometilação é um evento associado ao favorecimento da expressão gênica (RAZIN; CEDAR, 1991). Existem pelo menos dois mecanismos descritos que explicam esse fenômeno: 1) a metilação no DNA impede diretamente a acessibilidade de fatores transcricionais ao DNA e 2) a metilação no DNA recruta proteínas como a $\mathrm{MCP} 2$, formando complexos que impedem a atuação da maquinaria de transcrição gênica (RAZIN, CEDAR, 1991). Estudos mais recentes ampliam essa lógica mostrando que a metilação do DNA é capaz 
de provocar um remodelamento na cromatina, explicado parcialmente pelo recrutamento de enzimas histonas desacetilases (HDAC), que são responsáveis pela remoção enzimática de grupamento acetil de aminoácidos lisina constituintes da cauda peptídica N-terminal das histonas H3 e H4, principalmente (BIRD, 2011). As consequências desse mecanismo serão detalhadas adiante.

No entanto, há estudos que evidenciam uma quebra nesse paradigma, como no DM2 em que genes envolvidos no metabolismo apresentam redução no grau de metilação e de expressão (KIRCHNER et al., 2016). De fato, a desmetilação de citosinas localizadas dentro ou próximas a sítios de reconhecimento de fatores transcricionais repressores facilita a ligação dos mesmos, e isso acarreta em repressão da expressão do gene. Apesar disso, todos os estudos que até o momento avaliaram o grau de metilação da região promotora do gene Slc2a4 corroboram a visão clássica, ou seja, demonstraram uma correlação inversa com a atividade transcricional.

A concomitante hipermetilação de sítios $\mathrm{CpG}$ localizados no promotor do gene Slc2a4 e redução da expressão do gene $S l c 2 a 4$ foi observada em músculo esquelético de ratos adultos que receberam excesso de nutrientes no período pós-natal (LIU et al., 2013), ou que foram expostos ao ftalato, um composto presente em plásticos, durante a gestação materna (RAJESH; BALASUBRAMANIAN, 2014). Recentemente foi demonstrado que o aumento no grau de metilação de uma citosina no domínio de ligação do fator Sp1 na região promotora do gene Slc2a4, impede a ligação do Sp1 e, consequentemente, reduz a expressão do gene Slc2a4 (RÜEGG et al., 2011). Esse último estudo exemplifica um mecanismo pelo qual a metilação do DNA pode interferir na maquinaria transcricional do Slc2a4. Apesar desses estudos terem mostrado correlações interessantes entre o grau de metilação e a expressão do Slc2a4, ainda não há evidências na literatura, especificamente na condição do DM, acerca do envolvimento da metilação na região promotora do gene $S l c 2 a 4$ em músculo esquelético.

Outra importante regulação epigenética da maquinaria transcricional é a modificação pós-traducional (do inglês PTM) da extremidade N-terminal das histonas, principalmente da histona H3 (STRAHL; ALLIS, 2000). No núcleo das células, as histonas formam octâmeros compostos por dímeros dos 4 tipos de histonas (H2A, H2B, H3 e H4), e a dupla fita de DNA (aproximadamente 147 pares de bases) se enovela a esses octâmeros formando os conhecidos nucleossomos (OUDET; GROSS-BELLARD; CHAMBON, 1975). Os níveis de organização funcional dos nucleossomos ainda não foram totalmente elucidados devido a limitações metodológicas, mas o que se sabe é que a formação dos nucleossomos é o estágio mais simples de organização da cromatina, que implica em última instância na regulação da função do material gênico (CAVALLI, 2011). 
Os nucleossomos são unidades funcionais capazes de sofrer alterações dinâmicas, a partir de PTMs das histonas, que afetam diretamente a expressão gênica (MARIÑO-RAMÍREZ et al., 2005). Existem inúmeras PTMs, que incluem acetilação/metilação/ubiquitinação/sumoilação de lisina, metilação/citrulinação de arginina, ADP-ribosilação e isomerização de prolina e fosforilação de serina, treonina e tirosina (ROTHBART; STRAH, 2014). Dentre essas modificações, as mais estudadas são a acetilação e a metilação de lisinas pertencentes à extremidade N-terminal das histonas.

A hiperacetilação de lisinas das histonas favorece o estado conformacional conhecido como eucromatina, o que permite maior acessibilidade de fatores transcricionais ao DNA e, em geral, associa-se esse estado ao aumento da expressão gênica. O inverso, a hipoacetilação, promove um condensamento dos nucleossomos, estado de heterocromatina, que dificulta a interação de fatores transcricionais ao DNA e consequentemente, em geral, esse mecanismo está associado à repressão da expressão gênica (VERDONE; CASERTA; DI MAURO, 2005). O mecanismo de alteração conformacional dos nucleossomos envolve alteração na carga elétrica dos resíduos de aminoácidos que sofrem acetilação. Mecanisticamente, a acetilação de lisinas neutraliza a carga elétrica dos mesmos, evento que resulta na repulsão entre o octâmero de histonas e a dupla fita de DNA, explicando o mecanismo físico pelo qual a acetilação de histonas está associada ao estado conformacional menos compactado do material gênico. (GARDNER; ALLIS; STRAHL, 2011; KOUZARIDES, 2007).

Já a metilação dos resíduos lisina e arginina das extremidades N-terminal das histonas pode ativar ou reprimir a expressão gênica, mecanismo que depende da posição do resíduo que sofrer essa modificação (BLACK et al., 2012). É importante enfatizar que a metilação/desmetilação de histonas não altera diretamente o estado conformacional dos nucleossomos, mas altera o recrutamento de proteínas, que associadas formam complexos capazes de regular a transcrição, alterando indiretamente a conformação dos nucleossomos (KOUZARIDES, 2007). A trimetilação do resíduo lisina localizado na posição 9 da cauda peptídica N-terminal de histona $\mathrm{H} 3$ (H3K9me3) é associada à repressão transcricional (GREER; SHI, 2012), enquanto que a metilação do resíduo lisina localizado na posição 4 da cauda peptídica N-terminal de histona $\mathrm{H} 3$ (H3K4me) é associada à ativação transcricional (BERNSTEIN et al., 2002).

Alguns estudos já investigaram a influência da acetilação e metilação das histonas na expressão do gene $S l c 2 a 4$. Foi demonstrado que a hiperacetilação da H3 na região de ligação do MEF2 aumenta a ligação deste fator no promotor do gene Slc2a4, resultando em aumento da sua expressão (SMITH et al., 2008). Resultados semelhantes foram descritos por Mukwevho 
e colaboradores (2008) em modelo de incubação aguda (2 horas) de células musculares (C2C12) com cafeína $(10 \mathrm{mM})$. Adicionalmente, outro estudo demonstrou que a exposição à dieta rica em carboidratos no período neonatal promove, na vida adulta e no músculo esquelético, aumento no conteúdo de metilação na lisina 16 da histona H4 (H4K16me), perto do sítio de ligação do receptor do hormônio tireoidiano (TR) no promotor do gene Slc2a4, reduzindo a ligação do TR e a expressão do gene Slc2a4 e da proteína GLUT4 (RAYCHAUDHURI et al., 2014).

No entanto, nenhum estudo investigou tais mecanismos no gene Slc2a4 em modelo de diabetes, o que pode contribuir na determinação de novos reguladores desse gene, visando melhorar a homeostasia glicêmica no DM. Nesse sentido, destacam-se os polifenóis, abundantes micronutrientes não-essenciais classicamente conhecidos como anti-oxidantes (LANDETE, 2013).

Os polifenóis são encontrados em diversos tipos de alimentos como frutas, verduras, cereais e bebidas, incluindo o café, variados tipos de chás e vinhos (SCALBERT et al., 2005). Nos últimos anos, o conhecimento acerca das ações biológicas dos polifenóis expandiu, e estudos destacam um potente efeito no remodelamento da cromatina, afetando a expressão de genes por meio de variados mecanismos epigenéticos, que incluem a metilação do DNA e as PTMs de histonas. No entanto, a maioria dos estudos que investigaram o efeito dos polifenóis sobre mecanismos epigenéticos o fizeram em modelos experimentais relacionados a diversos tipos de câncer (GROH et al., 2013; KUMAR et al., 2015; VANDEN BERGHE, 2012). Nesse contexto, há indícios de que os polifenóis regulem a atividade das enzimas responsáveis pela metilação/desmetilação do DNA, como é o caso da epigalocatequina-3-galato e da genisteína, que são polifenóis encontrados na planta Camellia sinensis (chá verde) e na Glycine max (soja), respectivamente (FANG et al., 2007), bem como também há evidências de que outros polifenóis regulem PTMs das histonas, regulando a atividade de histonas acetiltransferases, desacetilases, metilases e desmetilases (KIM et al., 2016).

Outros estudos demonstram que os polifenóis também regulam marcações epigenéticas em genes envolvidos na gênese e progressão de outras doenças que não o câncer, tais como doenças cardiovasculares, neuro-degenerativas e distúrbios metabólicos que incluem o DM e a obesidade. Nesse sentido, é fundamental aprofundar a investigação desses compostos na fisiopatologia do DM (RUSSO et al., 2015).

Existem aproximadamente 8000 polifenóis e todos possuem, em sua estrutura química, anéis fenólicos com um ou mais grupamentos hidroxila (AYISSI; EBRAHIMI; SCHLUESENNER, 2014). Conforme a natureza do esqueleto de carbono, os polifenóis podem 
ser classificados em quatro grupos: flavonoides, ácidos fenólicos, estilbenos e ligninas (SCALBERT; WILLIAMSON, 2000). O resveratrol, foco do presente estudo, pertence ao grupo estilbeno, e é encontrado em abundância em diversas espécies de plantas, incluindo determinadas frutas como uva e amora, e estendendo-se ao vinho.

Assim como todos os polifenóis, em plantas, o resveratrol é produzido em resposta a agentes agressores como fungos, parasitas, radiação UV e substâncias químicas que, em geral, são fatores estressantes (GAMBINI et al., 2015). A fórmula química estrutural do resveratrol foi identificada a partir de sua extração da raíz da Veratrum grandiflorum (TAKAOKA, 1940), e consiste em dois anéis fenólicos unidos por dupla ligação de estireno, o que permite a formação de isomeria -cis e -trans, ilustradas na figura abaixo.

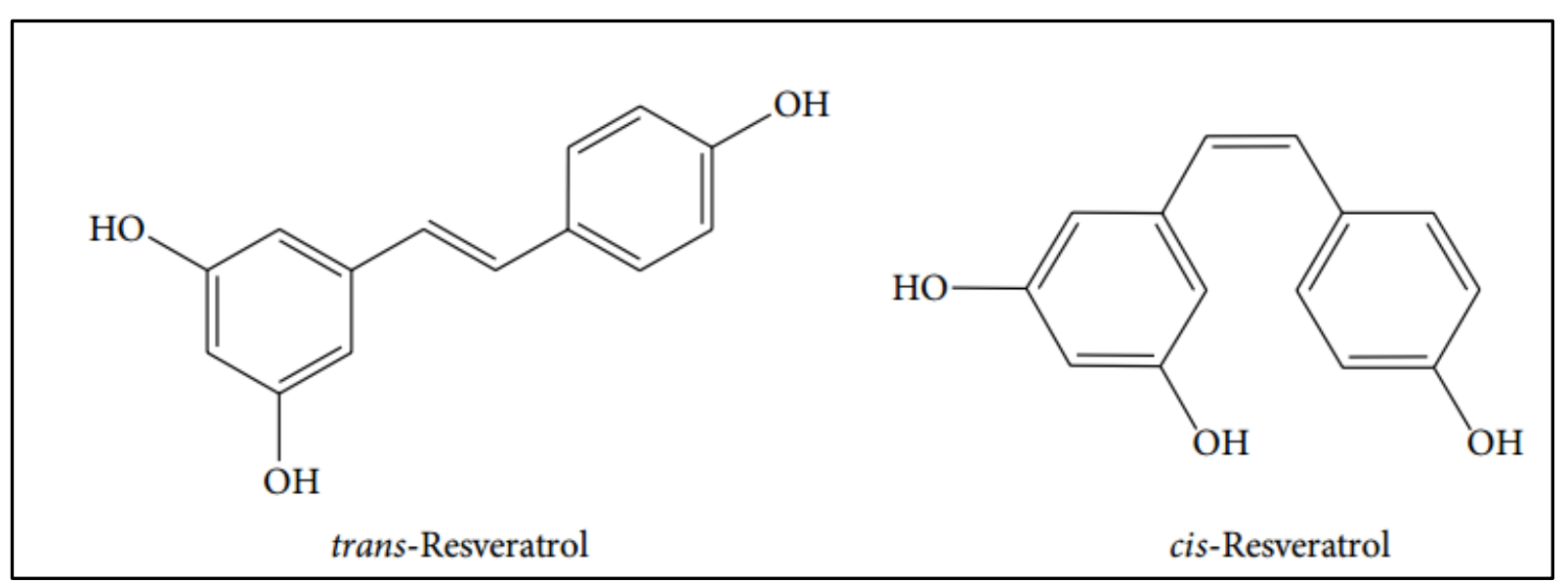

Figura 3- Estrutura química do trans-resveratrol e do cis-resveratrol.

É importante salientar que o trans-resveratrol é a isoforma mais estudada tanto em modelos experimentais (in vitro e in vivo), devido a sua maior estabilidade, apesar de apresentar baixa solubilidade em água ( $3 \mathrm{mg} / 100 \mathrm{~mL})$, e moderada solubilidade em álcool $(50 \mathrm{mg} / \mathrm{mL})$ e em dimetilsulfóxido (DMSO) (16 mg/mL) (DELMAS, 2011).

Apesar de diversos estudos até o momento terem reportado efeitos benéficos do resveratrol, a sua farmacocinética ainda é muito pouco conhecida. Em humanos, ensaios de rastreamento do resveratrol após administração oral aguda $(0,35 \mathrm{mg} / \mathrm{Kg}$ de peso corporal) demonstram que após 30 minutos há um pico de resveratrol livre na corrente sanguínea, mas que equivale a apenas $1,5 \%$ do total administrado. $O$ restante apresenta-se nas formas conjugadas com ácido glicurônico ou sulfato, indicando que o resveratrol sofre intensa e rápida metabolização in vivo (BOOCOCK et al., 2007; GOLDBERG; YAN; SOLEAS, 2003). O trânsito do resveratrol na corrente sanguínea é dependente de interações principalmente com 
proteínas e lipoproteínas plasmáticas, fato decorrente da baixa hidrosolubilidade desses compostos, enquanto que os metabólitos do resveratrol são hidrosolúveis (DELMAS, 2011).

Apesar das limitações relacionadas à baixa biodisponibilidade in vivo, há cerca de 25 anos as propriedades terapêuticas do resveratrol foram associadas ao consumo regular de vinho pela população francesa e sua baixa incidência de mortes por doença cardiovascular, apesar do baixo nível de atividade física e consumo elevado de alimentos gordurosos e tabaco. Na época, esse dado ficou popularmente conhecido como paradoxo francês (RENAUD; LORGERIL, 1992). Em seguida, o possível efeito cardioprotetor do resveratrol foi reiterado pela redução do dano no miocárdio, induzida por isquemia, da oxidação de LDL e da agregação plaquetária (WU et al., 2001). A partir de então, diversos estudos demonstraram que o resveratrol possui propriedades anti-envelhecimento, anti-inflamatória, anti-oxidante e anti-cancerígena (KASIOTIS et al., 2013; MOMKEN et al. 2011; PRASAD, 2012; ZHU et al., 2012). Recentemente, estudos demonstraram que o tratamento com resveratrol também possui efeitos anti-diabetogênicos, sendo capaz de promover melhorias em situações de resistência à ação da insulina e disfunção das células $\beta$ pancreática, associadas ou não à obesidade (SMOLIGA; BAUR; HAUSENBLAS, 2011; SZKUDELSKI; SZKUDELSKA, 2011).

O tratamento com resveratrol parece ser capaz de promover melhorias na sensibilidade à ação da insulina em modelos de DM1 e DM2 (SZUDELSKI; SZKIDELSKA, 2015). Há dados recentes confirmando que a resistência à insulina também está presente no DM1 (BACHA; KLINEPETER BARTZ, 2015; OKAMOTO et al., 2011) e, portanto, a investigação das ações do resveratrol sobre a sensibilidadeà insulina é relevante para ambos os tipos de DM (LEBOVITZ, 2010).

Poucos estudos investigaram o efeito do resveratrol em modelo DM1, sobre tudo em relação à homeostasia glicêmica e expressão de GLUT4 no músculo esquelético. Ainda, os poucos dados encontrados na literatura são conflitantes: alguns reportam melhoria sobre a homeostasia glicêmica e incluem aumento na expressão de GLUT4 (CHEN et al., 2011; CHI et al., 2007; PENUMATHSA et al., 2008), enquanto outros não observaram o mesmo efeito (SCHMATZ et al., 2009). Ainda, é importante salientar que nesses estudos nenhuma reposição de insulina foi utilizada, fato imprescindível no tratamento do DM1 (LEBOVITZ, 2010).

Outra parcela dos estudos, que são maioria, demonstraram efeitos do resveratrol na redução da glicemia em modelos animais de DM2 (CHEN et al., 2012) e em humanos DM2 (BHATT; THOMAS; NANJAN, 2012).

Em camundongos $d b / d b$, o tratamento com resveratrol parece estimular a translocação de GLUT4 e aumentar a captação de glicose em músculo esquelético (DO et al., 2012). Além 
disso, há indícios de um efeito protetor sobre as células B pancreáticas envolvendo a inibição do estresse oxidativo gerado pela ação de produtos de glicação avançada. Tais efeitos benéficos do resveratrol sobre a homeostasia glicêmica podem ainda ser associados ao aumento significativo do peso do pâncreas, massa das células B e redução da fibrose das ilhotas em camundongos $d b / d b$ tratados com $20 \mathrm{mg} / \mathrm{kg} / \mathrm{dia}$ de resveratrol (MINAKAWA et al., 2011). Dose mais elevada de resveratrol $(400 \mathrm{mg} / \mathrm{Kg} / \mathrm{dia})$ promove efeito protetor semelhante sobre a função do pâncreas por atenuar o estresse oxidativo (ZHANG et al., 2012). Adicionalmente, estudos in vitro demonstraram que tanto células INS-1E, quanto ilhotas humanas provenientes de um doador portador de DM2, quando incubadas com resveratrol na dose de $25 \mu \mathrm{M}$ apresentam aumento significante na secreção de insulina em resposta a sobrecarga de glicose (VETTERLI et al., 2011).

Portanto, os efeitos benéficos do resveratrol no DM2 parecem envolver uma melhora da sensibilidade à insulina e concomitante preservação da função das células $\mathrm{B}$, apesar deste último ser relevante somente quando há uma população residual de células $\mathrm{B}$, como evidenciado em estágios menos avançados de DM2 (WEYER et al., 1999).

Adicionalmente, há dados importantes na literatura sugerindo papel anti-obesidade do resveratrol (FERNÁNDEZ-QUINTELA et al., 2015). A obesidade, cuja incidência cresce exponencialmente, é um importante fator de risco para a gênese e progressão do DM2 (KAHN; HULL; UTZSCHNEIDER, 2006), e estudos em células adiposas, in vitro, mostram que o resveratrol, de maneira dose- e tempo-dependente promove a inibição da transcrição de genes e da tradução de proteínas envolvidas na lipogênese, destacando-se o PPAR gama, C/EBP-alfa e SREBP-1c (LASA et al., 2012). Lagouge e colaboradores (2006) foram os pioneiros em investigar as possíveis ações anti-obesidade do resveratrol, in vivo, demonstrando que camundongos C57BL/6J submetidos à dieta hiperlipídica recebendo resveratrol (200 ou 400 $\mathrm{mg} / \mathrm{Kg}$ de peso corporal, durante 15 semanas) apresentaram perda de peso, redução do tamanho de adipócitos, e aumento do metabolismo basal, demonstrado pelo aumento da expressão de PGC-1-alfa e UCP-1 no tecido adiposo marrom. Outros autores verificaram resultados semelhantes, inclusive estendendo o protocolo de tratamento com resveratrol até 55 semanas (BAUR et al., 2006) e utilizando variadas doses (1, 10 e $30 \mathrm{mg} / \mathrm{Kg} / \mathrm{dia})$ (CHANG et al., 2016).

Paralelamente aos efeitos gerais do resveratrol comentados até aqui, no contexto celular e molecular, existem informações limitadas na literatura acerca de seu mecanismo de ação. Primeiramente, a maior parte do resveratrol parece se difundir passivamente pela membrana plasmática, mas alternativamente pode interagir com receptores de membrana, as integrinas ( $\alpha v \beta 3)$, e nesse caso, mais especificamente pode ligar-se a subunidade $\beta 3$, ativando cascata de 
sinalização intracelular envolvida na atenuação da apoptose celular, efeito bem caracterizado em células de câncer de mama humano (LIN et al., 2006).

Há alguns mecanismos propostos de atuação do resveratrol no compartimento intracelular. O primeiro a ser descrito envolve a interação com receptor hidrocarboneto aril, codificado pelo gene $A H R$ (em humanos); foi descrito que o resveratrol inibe a transativação desse receptor promovendo a inibição da expressão de citocromo P-450 e interleucina 1-b, proteínas envolvidas na carcinogênese e imunossupressão, mecanismo que contribuiria para sua ação anti-carcinogênica (CASPER et al., 1999). Ainda, pelo fato do resveratrol ser considerado um fitoestrógeno, estudos demonstram que o resveratrol possui afinidade de ligação com os receptores de estrógeno alfa e beta, caracterizando mais um mecanismo de ação (BOWERS et al., 2000; GEHM et al., 1997).

No entanto, as inúmeras ações benéficas do resveratrol apontadas pela literatura parecem serem promovidas, principalmente, pela ativação de uma classe de enzimas chamadas de sirtuínas (SIRT) (BORRA; SMITH; DENU, 2005). As sirtuínas são codificadas por genes homólogos ao gene SIR2, presente em organismos mais simples como Caenorhabditis elegans. Em mamíferos, existem sete isoformas de SIRT (SIRT1-7), cada uma delas atua em diferentes compartimentos celulares (núcleo, citoplasma e mitocôndria), e todas elas apresentam em comum um domínio catalítico, onde se liga o co-fator $\mathrm{NAD}^{+}$; portanto, a modulação de sua atividade possui interface direta com o metabolismo (FLICK; LÜSCHER, 2012; IMAI et al., 2000; TANNO et al., 2007). Dependendo da isoforma e da sua localização intracelular, as sirtuínas possuem diversas atividades catalíticas que inclui desacetilação, ADP-ribosilação, demalonilação, desuccinação, dentre outras. A SIRT1 é a isoforma mais estudada, possui atividade desacetilase e maior homologia com o gene ancestral SIR2 (GUARENTE, 2013).

Conforme o tipo celular e o estágio de diferenciação em que uma dada célula se encontra, a SIRT1 pode ser encontrada tanto no compartimento citosólico quanto nuclear. Pelo fato da SIRT1 ser uma proteína de peso molecular hipotético de $\sim 120 \mathrm{kD}$, o seu trânsito através da carioteca não ocorre por simples difusão, mas depende de mecanismo específico. Este mecanismo envolve a existência de duas sequências de aminoácidos, na cauda $\mathrm{N}$-terminal, que sinalizam a importação e exportação nuclear (TANNO et al., 2007). Dessa maneira, há a possibilidade da SIRT1 atuar diretamente no núcleo, controlando processos relacionados à transcrição gênica, bem como no citosol, regulando vias de sinalização envolvidas em processos celulares como metabolismo, inflamação, estresse oxidativo e apoptose.

A SIRT1 é considerada uma importante proteína reguladora da homeostasia metabólica, sendo até sugerida como alvo importante no tratamento do DM (CHANG; GUARENTE, 2014; 
KUME et al., 2010). Classicamente, a restrição calórica é capaz de ativar a SIRT1 (GUARENTE, 2013), e o resveratrol mimetizaria os efeitos da restrição calórica, uma vez que é um potente ativador de SIRT1 (ALCAÍN; VILLALBA, 2009).

Em camundongos saudáveis submetidos à restrição alimentar foi detectado um aumento significante da atividade de SIRT1, acompanhado de redução da concentração plasmática de insulina, glicose e colesterol. Ainda, em modelos in vivo de resistência à insulina, a superexpressão de SIRT1 promoveu melhorias na tolerância à glicose, devido a uma redução da produção hepática de glicose e aumento dos níveis de adiponectina (hormônio produzido no tecido adiposo com ações sensibilizadoras à insulina) (BANKS et al., 2008). Em ratos SpragueDawley saudáveis submetidos à restrição calórica de 4 semanas $(60 \%$ de calorias da dieta normal) e, em seguida, submetidos à dieta normal, foi observada uma resistência à insulina, fenômeno descrito na literatura como catch-up. No entanto, após esses animais serem tratados, durante 12 semanas, com resveratrol (100 mg/kg/d), os mesmos apresentaram, em músculo tibial anterior, aumento da atividade de SIRT1, concomitantemente a um aumento na atividade mitocondrial e na sensibilidade à ação da insulina, reforçando que o resveratrol seja eficaz no tratamento de distúrbios metabólicos (ZHENG et al., 2012). Com base nessa última informação, é possível que o aumento da atividade de SIRT1, induzido pelo resveratrol, envolva regulação importante na expressão do gene Slc2a4 em músculo esquelético de modelos experimentais de $\mathrm{DM}$, o que nunca foi investigado.

Adicionalmente, o resveratrol é capaz de ativar a proteína cinase ativada por AMP (AMPK), que assim como a SIRT1, é considerada um importante sensor metabólico (FULLERTON; STEINBERG, 2010; KAHN et al., 2005). Como o próprio nome indica, a sua atividade está diretamente relacionada ao aumento nos níveis de AMP intracelulares. A AMPK é um complexo heterotrimérico, composto por três subunidades distintas $(\alpha, \beta$ e $\gamma$ ), as quais possuem, cada uma, três isoformas conhecidas, denominadas como 1, 2 e 3. A subunidade regulatória $\gamma$, reconhece o aumento dos níveis de AMP, o qual interage com esta subunidade, promovendo uma mudança conformacional, expondo o sítio catalítico da subunidade $\alpha$ a proteínas cinases, como LKB1 e CAMKII, e aumentando a atividade do complexo (FRIEDRICHSEN et al., 2013). Do ponto de vista farmacológico, diversos trabalhos demonstram que o resveratrol é capaz de aumentar a atividade de AMPK por meio de fosforilação no sítio treonina 172 da subunidade catalítica $\alpha$ (BREEN et al., 2008; ITONAGAHATA et al., 2013; PENUMATHSA et al., 2008).

Do e colaboradores (2012) demonstraram que os efeitos benéficos sobre a homeostasia glicêmica em camundongos $d b / d b$ envolve aumento na atividade da AMPK. De fato, 
camundongos $\mathrm{AMPKa}^{-/-}$e $\mathrm{AMPKa} 2^{-/-}$tratados com resveratrol não apresentam melhorias sobre a homeostasia glicêmica, como observado nos animais nativos (UM et al., 2010). No entanto, Price e colaboradores (2012) demonstraram que a atividade da AMPK é dependente da SIRT1, enquanto Cantó e colaboradores (2010) afirmaram o oposto, que a AMPK ativa a enzima NAMPT, responsável pela produção de $\mathrm{NAD}^{+}$(esse é co-fator essencial para atividade de SIRT1). Com base nesses dados, a princípio os efeitos do resveratrol na melhoria da homeostasia glicêmica devem envolver a atividade de ambas as proteínas (AMPK e SIRT1), mas isso ainda carece de maiores esclarecimentos no DM.

Em relação aos efeitos do resveratrol mediados pela SIRT1, tem sido proposta a participação de mecanismos epigenéticos (BAGUL et al., 2015; FARGHALI; KUTINOVÁ CANOVÁ; LEKIC, 2013). A SIRT1 é conhecida como uma histona desacetilase capaz de diretamente reduzir o grau de acetilação de histonas, e de indiretamente alterar o grau de metilação de histonas e do DNA (ZHANG; KRAUS, 2010). Portanto, o resveratrol poderia, via ativação de SIRT1, regular mecanismos epigenéticos em importantes processos celulares que possam melhorar a sensibilidade à insulina, o que representa um importante alvo para tratamento do DM ainda não investigado (AL-HADDAD et al., 2016).

Como exposto até então, os efeitos benéficos do resveratrol sobre a homeostasia glicêmica devem envolver mecanismos ainda não elucidados, incluindo os epigenéticos, principalmente aqueles que se alteram no estado diabético. Entretanto, nada se sabe quanto à possibilidade do resveratrol, via mecanismos epigenéticos / SIRT1, regular a expressão do gene Slc2a4 em músculo de animais diabéticos. 


\section{CONCLUSÃO}

Os resultados obtidos no presente estudo evidenciam que, tanto em modelo de DM1 como de DM2, a repressão do gene Slc2a4 (codifica o GLUT4) em músculo esquelético associa-se a regulações epigenéticas, a saber: redução de acetilação de H3 no DM1 e aumento de trimetilação de H3 tanto no DM1 como no DM2.

No DM1, a insulinoterapia melhora o controle glicêmico e restaura a expressão de Slc2a4/GLUT4, com reversão das alterações epigenéticas do Slc2a4; o tratamento coadjuvante com resveratrol induz melhora adicional no controle glicêmico, porém sem alteração adicional na expressão de Slc2a4/GLUT4.

No DM2, o resveratrol, isoladamente, restaura o controle glicêmico e aumenta a expressão de Slc2a4/GLUT4, com reversão do aumento da trimetilação de H3.

As regulações epigenéticas do gene Slc2a4 observadas são mediadas, pelo menos em parte, pelo conteúdo de SIRT1 nuclear.

Em suma, o presente estudo revela pela primeira vez a ocorrência de regulações epigenéticas no gene Slc2a4 em músculo de animais diabéticos, com destaque para as modificações pós-traducionais de histona $\mathrm{H} 3$, e o tratamento com resveratrol modula algumas dessas alterações, melhorando o controle glicêmico. Esses resultados evidenciam o resveratrol como um sensibilizador da insulina, além de embasarem o desenvolvimento futuro de terapias epigenéticas que contribuam para o controle glicêmico dos portadores de DM. 


\section{REFERÊNCIAS*}

ALCAÍN F. J.; VILlalBA J. M. Sirtuin activators. Expert Opin. Ther. Pat., v. 19, n. 4, p. 403-414, 2009.

ANDREWS N. C.; FALLER D. V. A rapid micropreparation technique for extraction of DNAbinding proteins from limiting numbers of mammalian cells. Nucleic Acids Res., v. 19, n. 9, p. 2499, 1991.

ARMBRUSTER D. A. Fructosamine: structure, analysis, and clinical usefulness. Clin. Chem., v. 33, n. 12, p. 2153-2163, 1987.

AL-HADDAD R.; KARNIB N.; ASSAAD R. A.; BILEN Y.; EMMANUEL N.; GHANEM A.; YOUNES J.; ZIBARA V.; STEPHAN J. S.; SLEIMAN S. F. Epigenetic changes in diabetes. Neuroscience Lett., v. 20, n. 625, p. 64-69, 2016.

BACHA F.; KLINEPETER BARTZ S. Insulin resistance, role of metformin and other noninsulin therapies in pediatric type 1 diabetes. Pediatric Diabetes., v.17, n. 8, p. 545-558, 2016.

BAGUL P. K.; DEEPTHI N.; SULTANA R.; BANERJEE S.K. Resveratrol ameliorates cardiac oxidative stress in diabetes through deacetylation of NFkB-p65 and histone 3. J. Nutr. Biochem., v. 26, n. 11, p. 1298-1307, 2015.

BANKS A. S.; KON N.; KNIGHT C.; MATSUMOTO M.; GUTIÉRREZ-JUÁREZ R; ROSSETTI L.; GU W.; ACCILI D. SirT1 gain of function increases energy efficiency and prevents diabetes in mice. Cell Metab., v. 8, n. 4, p. 333-341, 2008.

BARRÈS R.; YAN J.; EGAN B.; TREEBAK J. T.; RASMUSSEN M.; FRITZ T.; CAIDAHL K.; KROOK A.; O'GORMAN D. J.; ZIERATH J. R. Acute exercise remodels promoter methylation in human skeletal muscle. Cell Metab., v. 15, n. 3, p. 405-411, 2012.

BAUR J. A.; PEARSON K. J.; PRICE N. L.; JAMIESON H. A.; LERIN C.; KALRA A.; PRABHU V. V.; ALLARD J. S.; LOPEZ-LLUCH G.; LEWIS K; PISTELL P. J.; POOSALA S.; BECKER K. G.; BOSS O.; GWINN D.; WANG M.; RAMASWAMY S.; FISHBEIN K. W.; SPENCER R. G; LAKATTA E. G.; LE COUTEUR D.; SHAW R. J.; NAVAS P.; PUIGSERVER P.; INGRAM D. K.; DE CABO R.; SINCLAIR D. A. Resveratrol improves health and survival of mice on a high-calorie diet. Nature., v. 444, n.7117, p. 337-342, 2006.

BERNSTEIN B. E.; HUMPHREY E. L.; ERLICH R. L.; SCHNEIDER R.; BOUMAN P.; LIU J. S.; KOUZARIDES T.; SCHREIBER S. L. Methylation of histone H3 Lys 4 in coding regions of active genes. Proc. Natl. Acad. Sci., v. 99, n. 13, p.8695-8700, 2002.

BESTOR T.; LAUDANO A.; MATTALIANO R.; INGRAM V. Cloning and sequencing of a cDNA encoding DNA methyltransferase of mouse cells. The carboxyl-terminal domain of the mammalian enzymes is related to bacterial restriction methyltransferases. J. Mol. Biol., v. 203, n. 4, p. 971-983, 1988.

*De acordo com:

ASSOCIAÇÃO BRASILEIRA DE NORMAS TÉCNICAS. NBR6023: informação e documentação: referências: elaboração. Rio de Janeiro, 2002. 
BHATT J. K.; THOMAS S.; NANJAN M. J. Resveratrol supplementation improves glycemic control in type 2 diabetes mellitus. Nutr. Res., v. 32, n. 7, p. 537-541, 2012.

BIRD A. Perceptions of epigenetics. Nature., v. 447, n. 7143, p. 396-398, 2007.

BIRD A. Putting the DNA back into DNA methylation. Nat. Genet., v. 43, n. 11, p. 1050-1051, 2011.

BLACK J. C.; VAN RECHEM C.; WHETSTINE J. R. Histone lysine methylation dynamics: establishment, regulation, and biological impact. Mol. Cell., v. 48, n. 4, p. 491-507, 2012.

BRASNYÓ P.; MOLNÁR G. A.; MOHÁS M.; MARKÓ L.; LACZY B.; CSEH J.; MIKOLÁS E.; SZIJÁRTÓ I A.; MÉREI A.; HALMAI R.; MÉSZÁROS L. G.; SÜMEGI B.; WITTMANN I. Resveratrol improves insulin sensitivity, reduces oxidative stress and activates the Akt pathway in type 2 diabetic patients. Br. J. Nutr., v. 106 n. 3, p. 383-389, 2011.

BREEN D. M.; SANLI T.; GIACCA A.; TSIANI E. Stimulation of muscle cell glucose uptake by resveratrol through sirtuins and AMPK. Biochem. Biophys. Res. Commun., n. 374, v. 1, p. $117-122,2008$.

BOOCOCK D. J.; FAUST G. E.; PATEL K. R.; SCHINAS A. M.; BROWN V. A.; DUCHARME M. P.; BOOTH T. D.; CROWELL J. A.; PERLOFF M.; GESCHER A. J.; STEWARD W. P.; BRENNER D. E. Phase I dose escalation pharmacokinetic study in healthy volunteers of resveratrol, a potential cancer chemopreventive agent. Cancer Epidemiol. Biomarkers Prev., v. 16, n. 6, p. 1246-1252, 2007.

BORRA M. T.; SMITH B. C.; DENU J. M. Mechanism of human SIRT1 activation by resveratrol. J. Biol. Chem., v. 280, n. 17, p. 17187-17195, 2005.

BOSCH-PRESEGUÉ L.; RAURELL-VILA H.; MARAZUELA-DUQUE A. KANEGOLDSMITH N.; VALLE A.; OLIVER J.; SERRANO L.; VAQUERO A. Stabilization of Suv39H1 by SirT1 is part of oxidative stress response and ensures genome protection. Mol Cell., v. 42, n. 2 p. 210-223, 2011.

BOWERS J. L.; TYULMENKOV V. V.; JERNIGAN S. C.; KLINGE C. M. Resveratrol acts as a mixed agonist/antagonist for estrogen receptors alpha and beta. Endocrinology., v. 141, n. 10, p.3657-3667, 2000.

BROZINICK J. T. JR.; MCCOID S. C.; REYNOLDS T. H.; NARDONE N. A.; HARGROVE D. M.; STEVENSON R. W.; CUSHMAN S. W.; GIBBS E. M. GLUT4 overexpression in db/db mice dose-dependently ameliorates diabetes but is not a lifelong cure. Diabetes., v. 50, n. 3, p. 593-600, 2001.

BUNYAN J.; MURRELL E. A.; SHAH P. P. The induction of obesity in rodents by means of monosodium glutamate. Br. J. Nutr., v. 35, n. 1, p. 25-39, 1976. 
CANTÓ C.; JIANG L. Q.; DESHMUKH A. S.; MATAKI C.; COSTE A.; LAGOUGE M.; ZIERATH J. R.; AUWERX J. Interdependence of AMPK and SIRT1 for metabolic adaptation to fasting and exercise in skeletal muscle. Cell Metab., v. 11, n. 3, p. 213-219, 2010.

CANZIO D.; CHANG E. Y.; SHANKAR S.; KUCHENBECKER K. M.; SIMON M. D.; MADHANI H. D; NARLIKAR G. J; AL-SADY B. Chromodomain-mediated oligomerization of HP1 suggests a nucleosome-bridging mechanism for heterochromatin assembly. Mol. Cell., v. 41, n. 1, p. 67-81, 2011.

CASPER R. F.; QUESNE M.; ROGERS I. M.; SHIROTA T.; JOLIVET A.; MILGROM E.; SAVOURET J. F. Resveratrol has antagonist activity on the aryl hydrocarbon receptor: implications for prevention of dioxin toxicity. Mol. Pharmacol., v. 56, n. 4, p. 784-790, 1999.

CAVALLI G. From linear genes to epigenetic inheritance of three-dimensional epigenomes. J. Mol. Biol. v. 409, n. 1, p.54-61, 2011.

CHANG H. C.; GUARENTE L. SIRT1 and other sirtuins in metabolism. Trends Endocrinol. Metab. v. 25, n. 3, p. 138-145, 2014.

CHANG C. C.; LIN K. Y.; PENG K. Y.; DAY Y. J.; HUNG L. M. Resveratrol exerts antiobesity effects in high-fat diet obese mice and displays differential dosage effects on cytotoxicity, differentiation, and lipolysis in 3T3-L1 cells. Endocr. J., v. 63, n. 2, p.169-178, 2016.

CHEN K. H.; CHENG M. L.; JING Y. H.; CHIU D. T.; SHIAO M. S.; CHEN J. K. Resveratrol ameliorates metabolic disorders and muscle wasting in streptozotocin-induced diabetic rats. Am. J. Physiol. Endocrinol. Metab., v. 301, n. 5, p.853-863, 2011.

CHEN S.; LI J.; ZHANG Z.; LI W.; SUN Y.; ZHANG Q.; FENG X.; ZHU W. Effects of resveratrol on the amelioration of insulin resistance in KKAy mice. Can. J. Physiol. Pharmacol., v. 90, n. 2, p. 237-242, 2012.

CHI T. C.; CHEN W. P.; CHI T. L.; KUO T. F.; LEE S. S. CHENG J. T.; SU M. J. Phosphatidylinositol-3-kinase is involved in the antihyperglycemic effect induced by resveratrol in streptozotocin-induced diabetic rats. Life Sci., v. 80, n. 18, p. 1713-1720, 2007.

COLEMAN S. K.; REBALKA I. A.; D'SOUZA D. M.; HAWKE T. J. Skeletal muscle as a therapeutic target for delaying type 1 diabetic complications. World J. Diabetes., v. 6, n. 17, p. 1323-1336, 2015.

COOKE D. W.; LANE M. D. Transcription factor NF1 mediates repression of the GLUT4 promoter by cyclic-AMP. Biochem Biophys Res Commun., v. 260, n. 3, p.600-604, 1999.

CORREAA-GIANNELLA M. L.; MACHADO U. F. SLC2A4 gene: a promising target for pharmacogenomics of insulin resistance. Pharmacogenomics., v. 14, n. 8, p. 847-850, 2013.

CRANDALL J. P. ORAM V.; TRANDAFIRESCU G.; REID M.; KISHORE P.; HAWKINS M.; COHEN H. W.; BARZILAI N. Pilot study of resveratrol in olderadults with impaired glucose tolerance. J Gerontol A Biol Sci Med Sci, v. 67, p.1307-1312, 2012. 
DE CARVALHO PAPA P.; VARGAS A. M.; DA SILVA J. L.; NUNES M. T.; MACHADO U. F. GLUT4 protein is differently modulated during development of obesity in monosodium glutamate-treated mice. Life Sci., v. 71, n. 16, p.1917-1928, 2002.

DEATON A. M.; BIRD A. CpG islands and the regulation of transcription. Genes Dev., v. 25, n. 10, p. 1010-1022, 2011.

DEGEETER M.; WILLIAMSON B. Alternative Agents in Type 1 Diabetes in Addition to Insulin Therapy: Metformin, Alpha-Glucosidase Inhibitors, Pioglitazone, GLP-1 Agonists, DPP-IV Inhibitors, and SGLT-2 Inhibitors. J. Pharm. Pract., v. 29, p. 144-159, 2014.

DELMAS D.; AIRES V.; LIMAGNE E.; DUTARTRE P.; MAZUÉ F.; GHIRINGHELLI F.; LATRUFFE N. Transport, stability, and biological activity of resveratrol. Ann. N. Y. Acad. Sci., v. 1215, p. 48-59, 2011.

DO G. M.; JUNG U. J.; PARK H. J.; KWON E. Y.; JEON S. M.; MCGREGOR R. A.; CHOI M. S. Resveratrol ameliorates diabetes-related metabolic changes via activation of AMPactivated protein kinase and its downstream targets in $\mathrm{db} / \mathrm{db}$ mice. Mol. Nutr. Food Res., v. 56, n. 8, p. 1282-1291, 2012.

DOWELL P.; COOKE D. W. Olf-1/early B cell factor is a regulator of glut4 gene expression in 3T3-L1 adipocytes. J. Biol. Chem., v. 277, n. 3, p. 1712-1718, 2002.

FANG M.; CHEN D.; YANG C. S. Dietary polyphenols may affect DNA methylation. J. Nutr., v. 137, (1 Suppl):223S-228S, 2007.

FARGHALI H.; KUTINOVÁ CANOVÁ N.; LEKIĆ N. Resveratrol and related compounds as antioxidants with an allosteric mechanism of action in epigenetic drug targets. Physiol. Res., v. 62 , n. 1, p. 1-13, 2013.

FLICK F.; LÜSCHER B. Regulation of sirtuin function by posttranslational modifications. Front Pharmacol., v.28, n.3, p. 29, 2012.

FRIEDRICHSEN M.; MORTENSEN B.; PEHMØLLER C.; BIRK J. B.; WOJTASZEWSKI J. F. P. Exercise-induced AMPK activity in skeletal muscle: role in glucose uptake and insulin sensitivity. Mol. Cell Endocrinol., v. 366, n. 2, p. 204-214, 2013.

FERNÁNDEZ-QUINTELA A.; CARPÉNÉ C.; FERNÁNDEZ M.; AGUIRRE L.; MILTONLASKIBAR I; CONTRERAS J; PORTILLO M. P. Anti-obesity effects of resveratrol: comparison between animal models and humans. J. Physiol. Biochem., 2015.

FULLERTON M. D.; STEINBERG G. R. SIRT1 takes a backseat to AMPK in the regulation of insulin sensitivity by resveratrol. Diabetes. v. 59, n. 3, p. 551-553, 2010.

FURUYA D. T.; POLETTO A. C.; FAVARO R. R.; MARTINS J. O.; ZORN T. M.; MACHADO U. F. Anti-inflammatory effect of atorvastatin ameliorates insulin resistance in monosodium glutamate-treated obese mice. Metabolism., v. 59, n. 3, p. 395-399, 2010.

FURUYA D. T.; NERI E. A.; POLETTO A. C.; ANHÊ G. F.; FREITAS H. S.; CAMPELLO R. S.; REBOUÇAS N. A.; MACHADO U. F. Identification of nuclear factor- $\kappa B$ sites in the Slc2a4 gene promoter. Mol. Cell Endocrinol., v. 370, n. 1-2, p. 87-95, 2013. 
GAMBINI J.; INGLÉS M.; OLASO G.; LOPEZ-GRUESO R.; BONET-COSTA V.; GIMENO-MALLENCH L.; MAS-BARGUES C.; ABDELAZIZ K. M.; GOMEZ-CABRERA M. C.; VINA J.; BORRAS C. Properties of Resveratrol: In Vitro and In Vivo Studies about Metabolism, Bioavailability, and Biological Effects in Animal Models and Humans. Oxid. Med. Cell Longev.,;2015:837042. 2015

GARDINER-GARDEN M.; FROMMER M. CpG islands in vertebrate genomes. J. Mol. Biol., v. 196, n. 2, p. 261-282, 1987.

GARDNER K. E.; ALLIS C. D.; STRAHL B. D. Operating on chromatin, a colorful language where context matters. J. Mol. Biol., v. 409, n.1, p. 36-46, 2011.

GARFIN D E. One-dimensional gel electrophoresis. Methods Enzymol., v. 182, p. 425-441, 1990.

GEHM B. D.; MCANDREWS J. M.; CHIEN P. Y.; JAMESON J. L. Resveratrol, a polyphenolic compound found in grapes and wine, is an agonist for the estrogen receptor. Proc. Natl. Acad. Sci., v. 94, n. 25, p. 14138-14143, 1997.

GENCOGLU H.; TUZCU M.; HAYIRLI A.; SAHIN K. Protective effects of resveratrol against streptozotocin-induced diabetes in rats by modulation of visfatin/sirtuin-1 pathway and glucose transporters. Int. J. Food Sci. Nutr., v. 66, n. 3, p. 314-320, 2015.

GIBBS E. M.; STOCK J. L.; MCCOID S. C.; STUKENBROK H. A.; PESSIN J. E.; STEVENSON R. W.; MILICI A. J.; MCNEISH J. D. Glycemic improvement in diabetic db/db mice by overexpression of the human insulin-regulatable glucose transporter (GLUT4). J. Clin. Invest., v. 95, n. 4, p. 1512-1518, 1995.

GOLDBERG D. M.; YAN J.; SOLEAS G. J. Absorption of three wine-related polyphenols in three different matrices by healthy subjects. Clin. Biochem., v. 36, n. 1, p. 79-87, 2003.

GREER E. L.; SHI Y. Histone methylation: a dynamic mark in health, disease and inheritance. Nat. Rev. Genet., v. 13, n. 5, p. 343-357, 2012.

GROH I. A.; CHEN C.; LÜSKE C.; CARTUS A. T.; ESSELEN M. Plant polyphenols and oxidative metabolites of the herbal alkenylbenzene methyleugenol suppress histone deacetylase activity in human colon carcinoma cells. J. Nutr. Metab., v 2013;2013:821082.

GUARENTE L. Calorie restriction and sirtuins revisited. Genes Dev., v. 27, n.19, p.2072-2085, 2013.

GURD B. J.; YOSHIDA Y.; MCFARLAN J. T.; HOLLOWAY G. P.; MOYES C. D.; HEIGENHAUSER G. J.; SPRIET L.; BONEN A. Nuclear SIRT1 activity, but not protein content, regulates mitochondrial biogenesis in rat and human skeletal muscle. Am. J. Physiol. Regul. Integr. Comp. Physiol., v. 301, n. 1, p. 67-75, 2011.

GUT P.; VERDIN E. The nexus of chromatin regulation and intermediary metabolism. Nature., v. 502, n. 7472, p. 489-498, 2013. 
HAMIDI T.; SINGH A. K.; CHEN T. Genetic alterations of DNA methylation machinery in human diseases. Epigenomics., v. 7, n. 2, p. 247-265, 2015.

HAN L.; ZHAO Z. CpG islands or CpG clusters: how to identify functional GC-rich regions in a genome? BMC Bioinformatics., v. 10, n. 65, 2009.

HORI Y. S.; KUNO A.; HOSODA R.; HORIO Y. Regulation of FOXOs and p53 by SIRT1 modulators under oxidative stress. PLoS One., v. 8, n. 9, p.738-775, 2013.

ILLINGWORTH R. S.; BIRD A. P. CpG islands: 'a rough guide'. FEBS Lett., v. 583, n. 11, p. 1713-1720, 2009.

IM S. S.; KWON S. K.; KIM T. H.; KIM H. I.; AHN Y. H. Regulation of glucose transporter type 4 isoform gene expression in muscle and adipocytes. IUBMB Life., v. 59, n. 3, p. 134$145,2007$.

IMAI S.; ARMSTRONG C. M.; KAEBERLEIN M.; GUARENTE L. Transcriptional silencing and longevity protein Sir2 is an NAD-dependent histone deacetylase. Nature., v. 403, n. 6771, p. 795-800, 2000.

INOUE H, NAKATA R. Resveratrol Targets in Inflammation. Endocr. Metab. Immune Disord. Drug Targets., v. 15, n. 3, p. 186-195, 2015.

ITO-NAGAHATA T.; KURIHARA C.; HASEBE M.; ISHII A.; YAMASHITA K.; IWABUCHI M.; SONODA M.; FUKUHARA K.; SAWADA R.; MATSUOKA A.; FUJIWARA Y. Stilbene analogs of resveratrol improve insulin resistance through activation of AMPK. Biosci. Biotechnol. Biochem., v.77, n. 6, p. 1229-1235, 2013.

JAENISCH R.; BIRD A. Epigenetic regulation of gene expression: how the genome integrates intrinsic and environmental signals. Nat. Genet., v. 33, p. 245-254, 2003.

JEON B. T.; JEONG E. A.; SHIN H. J.; LEE Y.; LEE D. H.; KIM H. J.; KANG S. S.; CHO G. J.; CHOI W. S.; ROH G. S. Resveratrol attenuates obesity-associated peripheral and central inflammation and improves memory deficit in mice fed a high-fat diet. Diabetes., v. 61, n. 6, p. 1444-1454, 2012.

JEONG K.; KWON H.; LEE J.; JANG D.; PAK Y. Insulin-response epigenetic activation of Egr-1 and JunB genes at the nuclear periphery by A-type lamin-associated pY19-Caveolin-2 in the inner nuclear membrane. Nucleic Acids Res., v. 43, n. 6, p. 3114-3127, 2015.

KAHN B. B.; ALQUIER T.; CARLING D.; HARDIE D. G. AMP-activated protein kinase: ancient energy gauge provides clues to modern understanding of metabolism. Cell Metab., v. 1, n. 1, p. 15-25, 2005.

KAHN S. E.; HULL R. L.; UTZSCHNEIDER K. M. Mechanisms linking obesity to insulin resistance and type 2 diabetes. Nature., v. 444, n. 7121, p. 840-846, 2006.

KANG W.; HONG H. J.; GUAN J.; KIM D. G.; YANG E. J.; KOH G.; PARK D.; HAN C. H.; LEE Y. J.; LEE D. H. Resveratrol improves insulin signaling in a tissue-specific manner under 
insulin-resistant conditions only: in vitro and in vivo experiments in rodents. Metabolism., v. 61, n. 3, p. 424-433, 2012.

KARNIELI E.; ARMONI M. Transcriptional regulation of the insulin-responsive glucose transporter GLUT4 gene: from physiology to pathology. Am. J. Physiol. Endocrinol. Metab., v. 295, p. 1, p. 38-45, 2008.

KASIOTIS K. M.; PRATSINIS H.; KLETSAS D.; HAROUTOUNIAN S. A. Resveratrol and related stilbenes: their anti-aging and anti-angiogenic properties. Food Chem Toxicol., v. 61, p. 112-120, 2013.

KIM E.; BISSON W. H.; LÖHR C. V.; WILLIAMS D. E.; HO E.; DASHWOOD R. H.; RAJENDRAN P. Histone and Non-Histone Targets of Dietary Deacetylase Inhibitors. Curr. Top. Med. Chem., v. 16, n. 7, p. 714-731, 2016.

KIM S.; JIN Y.; CHOI Y.; PARK T. Resveratrol exerts anti-obesity effects via mechanisms involving down-regulation of adipogenic and inflammatory processes in mice. Biochem. Pharmacol., v. 81, n. 11, p. 1343-1351, 2011

KIRCHNER H.; OSLER M. E.; KROOK A.; ZIERATH J. R. Epigenetic flexibility in metabolic regulation: disease cause and prevention? Trends Cell. Biol., v.3, n. 5, p. 203-209, 2013.

KIRCHNER H.; SINHA I.; GAO H.; RUBY M. A.; SCHÖNKE M.; LINDVALL J. M.; BARRÈS R.; KROOK A.; NÄSLUND E.; DAHLMAN-WRIGHT K.; ZIERATH J. R. Altered DNA methylation of glycolytic and lipogenic genes in liver from obese and type 2 diabetic patients. Mol. Metab., v. 5, n. 3, p. 171-183, 2016.

KLEIN D.; KERN R. M.; SOKOL R. Z. A method for quantification and correction of proteins after transfer to immobilization membranes. Biochem. Mol. Biol. Int., v. 36, n. 1, p. 59-66, 1995.

KOISTINEN H. A.; ZIERATH J. R. Regulation of glucose transport in human skeletal muscle. Ann. Med.; v. 34, n. 6, p.410-418, 2002.

KOUZARIDES T. Chromatin modifications and their function. Cell., v. 128, n. 4, p. 693-705, 2007.

KUMAR A.; DHAR S.; RIMANDO A. M.; LAGE J. M.; LEWIN J. R.; ZHANG X.; LEVENSON A. S. Epigenetic potential of resveratrol and analogs in preclinical models of prostate cancer. Ann. N. Y. Acad Sci., v. 1348, n. 1, p. 1-9, 2015.

KUME S.; UZU T.; KASHIWAGI A.; KOYA D. SIRT1, a calorie restriction mimetic, in a new therapeutic approach for type 2 diabetes mellitus and diabetic vascular complications. Endocr. Metab. Immune Disord. Drug Targets., v. 10, n. 1, p. 16-24, 2010.

KWAK S. H.; PARK K. S. Recent progress in genetic and epigenetic research on type 2 diabetes. Exp. Mol. Med., v. 48, p. 220, 2016. 
LAGOUGE M.; ARGMANN C.; GERHART-HINES Z.; MEZIANE H.; LERIN C.; DAUSSIN F.; MESSADEQ N.; MILNE J.; LAMBERT P.; ELLIOTT P.; GENY B.; LAAKSO M.; PUIGSERVER P.; AUWERX J. Resveratrol improves mitochondrial function and protects against metabolic disease by activating SIRT1 and PGC-1alpha. Cell., v. 127, n. 6, p. 1109$1122,2006$.

LASA A.; CHURRUCA I.; ESEBERRI I.; ANDRÉS-LACUEVA C.; PORTILLO M. P. Delipidating effect of resveratrol metabolites in 3T3-L1 adipocytes. Mol. Nutr. Food Res., v. 56, n. 10, p. 1559-1568, 2012.

LANDETE J. M. Dietary intake of natural antioxidants: vitamins and polyphenols. Crit. Rev. Food Sci. Nutr., v. 53, n. 7, p. 706-721, 2013.

LEBOVITZ H. E. Adjunct therapy for type 1 diabetes mellitus. Nat. Rev. Endocrinol., v.6, n. 6, p. 326-334, 2010.

LEE B. C.; LEE J. Cellular and molecular players in adipose tissue inflammation in the development of obesity-induced insulin resistance. Biochim. Biophys. Acta., v. 1842, n. 3, p. 446-462, 2014.

LENZEN S. The mechanisms of alloxan- and streptozotocin-induced diabetes. Diabetologia., v. 51, n. 2, p. 216-226, 2008.

LIMA G. A.; ANHÊ G. F.; GIANNOCCO G.; NUNES M. T.; CORREA-GIANNELLA M. L.; MACHADO U. F. Contractile activity per se induces transcriptional activation of SLC2A4 gene in soleus muscle: involvement of MEF2D, HIF-1a, and TRalpha transcriptional factors. Am. J. Physiol. Endocrinol. Metab., v. 296, n. 1, p. 132-138, 2009.

LIN H. Y.; LANSING L.; MERILLON J. M.; DAVIS F. B.; TANG H. Y.; SHIH A.; VITRAC X.; KRISA S.; KEATING T.; CAO H. J.; BERGH J.; QUACKENBUSH S.; DAVIS P. J. Integrin alphaVbeta3 contains a receptor site for resveratrol. FASEB J., v. 20, n. 10, p. $1742-$ 1744, 2006.

LIU H. W.; MAHMOOD S.; SRINIVASAN M.; SMIRAGLIA D. J.; PATEL M. S. Developmental programming in skeletal muscle in response to overnourishment in the immediate postnatal life in rats. J. Nutr. Biochem., v. 24, n. 11, p. 1859-1869, 2013.

LIVAK K. J.; SCHMITTGEN T. D. Analysis of relative gene expression data using real-time quantitative PCR and the 2(-Delta Delta C(T)) Method. Methods., v. 25, n.4, p. 402-408, 2001.

LU C.; THOMPSON C. B. Metabolic regulation of epigenetics. Cell Metab., v. 16, n. 1, p. 9$17,2012$.

MACHADO U. F.; SHIMIZU Y.; SAITO M. Decreased glucose transporter (GLUT 4) content in insulin-sensitive tissues of obese aurothioglucose- and monosodium glutamate-treated mice. Horm. Metab. Res., v. 25, n. 9p. 462-465, 1993.

MACHADO U. F.; SHIMIZU I.; SAITO M. Reduced content and preserved translocation of glucose transporter (GLUT 4) in white adipose tissue of obese mice. Physiol. Behav., v. 55, n. 4, p. 621-625, 1994. 
MAITER D.; UNDERWOOD L. E.; MARTIN J. B.; KOENIG J. I. Neonatal treatment with monosodium glutamate: effects of prolonged growth hormone $(\mathrm{GH})$-releasing hormone deficiency on pulsatile GH secretion and growth in female rats. Endocrinology., v. 128, n. 2, p. 1100-1106, 1991.

MARIÑO-RAMÍREZ L.; KANN M. G.; SHOEMAKER B. A.; LANDSMAN D. Histone structure and nucleosome stability. Expert Rev. Proteomics., v. 2, n. 5, p. 719-729, 2005.

MENDES K. L.; DE PINHO L.; ANDRADE J. M.; PARAÍSO A. F.; LULA J. F.; MACEDO S. M.; FELTENBERGER J. D.; GUIMARÃES A. L.; DE PAULA A. M.; SANTOS S. H. Distinct metabolic effects of resveratrol on lipogenesis markers in mice adipose tissue treated with high-polyunsaturated fat and high-protein diets. Life Sci., v. 15, n. 153, p. 66-73, 2016.

MIAO F.; CHEN Z.; ZHANG L.; LIU Z.; WU X.; YUAN Y. C.; NATARAJAN R. Profiles of epigenetic histone post-translational modifications at type 1 diabetes susceptible genes. $\mathbf{J}$ Biol Chem., v. 287, n.20, p. 16335-16345, 2012.

MINAKAWA M.; KAWANO A.; MIURA Y.; YAGASAKI K. Hypoglycemic effect of resveratrol in type 2 diabetic model $\mathrm{db} / \mathrm{db}$ mice and its actions in cultured L6 myotubes and RIN-5F pancreatic $\beta$-cells. J. Clin. Biochem. Nutr., v. 48, n. 3, p. 237-244, 2011.

MIURA S.; TSUNODA N.; IKEDA S.; KAI Y.; COOKE D. W.; LANE M. D.; EZAKI O. Nuclear factor 1 regulates adipose tissue-specific expression in the mouse GLUT4 gene. Biochem. Biophys. Res. Commun., v. 325, n. 3, p. 812-818, 2004.

MOMKEN I.; STEVENS L.; BERGOUIGNAN A.; DESPLANCHES D.; RUDWILL F.; CHERY I.; ZAHARIEV A; ZAHN S.; STEIN T. P.; SEBEDIO J. L.; PUJOS-GUILLOT E.; FALEMPIN M.; SIMON C.; COXAM V.; ANDRIANJAFINIONY T.; GAUQUELIN-KOCH G.; PICQUET F.; BLANC S. Resveratrol prevents the wasting disorders of mechanical unloading by acting as a physical exercise mimetic in the rat. FASEB J., v. 25, n. 10, p. 36463660, 2011.

MORAES P. A.; YONAMINE C. Y.; PINTO JUNIOR D. C.; ESTEVES J. V.; MACHADO U. F.; MORI R. C. Insulin acutely triggers transcription of Slc2a4 gene: participation of the AT-rich, E-box and NFKB-binding sites. Life Sci., v. 114, n. 1, p. 36-44, 2014.

MORRIS M. J.; TORTELLI C. F.; FILIPPIS A.; PROIETTO J. Reduced BAT function as a mechanism for obesity in the hypophagic, neuropeptide $\mathrm{Y}$ deficient monosodium glutamatetreated rat. Regul. Pept., v. 75-76, p. 441-447, 1998.

MUKWEVHO E.; KOHN T. A.; LANG D.; NYATIA E.; SMITH J.; OJUKA E. O. Caffeine induces hyperacetylation of histones at the MEF2 site on the Glut4 promoter and increases MEF2A binding to the site via a CaMK-dependent mechanism. Am. J. Physiol. Endocrinol. Metab., v. 294, n. 3, p. 582-588, 2008.

MURATA M.; TAKAHASHI A.; SAITO I.; KAWANISHI S. Site-specific DNA methylation and apoptosis: induction by diabetogenic streptozotocin. Biochem. Pharmacol., v. 57, n. 8, p. 881-887, 1999. 
MURAYAMA A.; OHMORI K.; FUJIMURA A.; MINAMI H.; YASUZAWA-TANAKA K.; KURODA T.; OIE S.; DAITOKU H.; OKUWAKI M.; NAGATA K.; FUKAMIZU A.; KIMURA K.; SHIMIZU T.; YANAGISAWA J. Epigenetic control of rDNA loci in response to intracellular energy status. Cell., v. 133, n. 4, p. 627-639, 2008.

OAKES C. C.; LA SALLE S.; ROBAIRE B.; TRASLER J. M. Evaluation of a quantitative DNA methylation analysis technique using methylation-sensitive/dependent restriction enzymes and real-time PCR. Epigenetics., v. 1, n. 3, p. 146-152, 2006.

OLNEY J. W. Brain lesions, obesity, and other disturbances in mice treated with monosodium glutamate. Science., v.164, n. 3880, p.719-721, 1969.

OLSON A. L.; KNIGHT J. B. Regulation of GLUT4 expression in vivo and in vitro. Front. Biosci., v. 8, p. 401-409, 2003.

OUDET P.; GROSS-BELLARD M.; CHAMBON P. Electron microscopic and biochemical evidence that chromatin structure is a repeating unit. Cell., v. 4, n. 4, p. 281-300, 1975.

OKAMOTO M. M.; ANHÊ G. F.; SABINO-SILVA R.; MARQUES M. F.; FREITAS H. S.; MORI R. C.; MELO K. F.; MACHADO U. F. Intensive insulin treatment induces insulin resistance in diabetic rats by impairing glucose metabolism-related mechanisms in muscle and liver. J. Endocrinol., v. 211, n. 1, p. 55-64, 2011.

PAPA P. C.; SERAPHIM P. M.; MACHADO U. F. Loss of weight restores GLUT 4 content in insulin-sensitive tissues of monosodium glutamate-treated obese mice. Int. J. Obes. Relat. Metab. Disord., v. 21, n. 11, p. 1065-1070, 1997.

PATIL V.; WARD R. L.; HESSON L. B. The evidence for functional non-CpG methylation in mammalian cells. Epigenetics., v. 9, n. 6, p. 823-828, 2014.

PDRAW Versão 1.0 Revisão 1.1.122. ACACLONE. Software.

PENUMATHSA S. V.; THIRUNAVUKKARASU M.; ZHAN L.; MAULIK G.; MENON V. P.; BAGCHI D.; MAULIK N. Resveratrol enhances GLUT-4 translocation to the caveolar lipid raft fractions through AMPK/Akt/eNOS signalling pathway in diabetic myocardium. J. Cell Mol. Med., v. 12, n. 6A, p. 2350-2361, 2008.

PRASAD, K. Resveratrol, wine, and atherosclerosis. Int J Angiol., v. 21, n. 1, p. 7-18, 2012.

PRIMER 3. Versão: 0.4.0 Howard Hughes Medical Institute and by the National Institutes of Health, National Human Genome Research Institute.

QUANTE T.; BIRD A. Do short, frequent DNA sequence motifs mould the epigenome? Nat. Rev. Mol. Cell Biol., v. 17, n. 4, p. 257-262, 2016.

QIAO Y; SUN J.; XIA S.; TANG X.; SHI Y.; LE G. Effects of resveratrol on gut microbiota and fat storage in a mouse model with high-fat-induced obesity. Food Funct., v. 5, n. 6, p. 1241-1249, 2014. 
PRICE N. L.; GOMES A. P.; LING A. J.; DUARTE F. V.; MARTIN-MONTALVO A.; NORTH B. J.; AGARWAL B.; YE L.; RAMADORI G.; TEODORO J. S.; HUBBARD B. P.; VARELA A. T.; DAVIS J. G.; VARAMINI B.; HAFNER A.; MOADDEL R.; ROLO A. P.; COPPARI R.; PALMEIRA C. M.; DE CABO R.; BAUR J. A.; SINCLAIR D. A. SIRT1 is required for AMPK activation and the beneficial effects of resveratrol on mitochondrial function. Cell Metab., v. 15, n. 5, p. 675-690, 2012.

RAJESH P.; BALASUBRAMANIAN K. Phthalate exposure in utero causes epigenetic changes and impairs insulin signalling. J. Endocrinol., v. 223, n. 1, p. 47-66, 2014.

RASMUSSEN K. D.; HELIN K. Role of TET enzymes in DNA methylation, development, and cancer. Genes Dev., v. 30, n. 7, p. 733-750, 2016.

RAZIN A.; CEDAR H. DNA methylation and gene expression. Microbiol. Rev., v. 55, n. 3, p. 451-458, 1991.

RAYCHAUDHURI N.; THAMOTHARAN S.; SRINIVASAN M.; MAHMOOD S.; PATEL M. S.; DEVASKAR S. U. Postnatal exposure to a high-carbohydrate diet interferes epigenetically with thyroid hormone receptor induction of the adult male rat skeletal muscle glucose transporter isoform 4 expression. J. Nutr. Biochem., v. 25, n. 10, p. 1066-1076, 2014.

REFFINDER. c2014. Disponível em:

$<$ http://www.leonxie.com/referencegene.php?type=reference $>$. Acesso: 20 de agosto de 2014.

RENAUD S.; DE LORGERIL M. The French paradox: dietary factors and cigarette smokingrelated health risks. Ann. N. Y. Acad. Sci., v. 686, p. 299-309, 1993.

RICHARDSON J. M.; PESSIN J. E. Identification of a skeletal muscle-specific regulatory domain in the rat GLUT4/muscle-fat gene. J. Biol. Chem., v. 268, n. 28, p. 21021-21027, 1993.

ROBERTSON K. D. DNA methylation, methyltransferases, and cancer. Oncogene., v. 20, n. 24, p. 3139-3155, 2001.

ROTHBART S. B.; STRAHL B. D. Interpreting the language of histone and DNA modifications. Biochim. Biophys. Acta., v. 1839, n. 8, p. 627-643, 2014.

ROMERO-CALVO I.; OCÓN B.; MARTÍNEZ-MOYA P.; SUÁREZ M. D.; ZARZUELO A.; MARTÍNEZ-AUGUSTIN O.; DE MEDINA F. S. Reversible Ponceau staining as a loading control alternative to actin in Western blots. Anal. Biochem., v. 401, n. 2, p. 318-320, 2010.

RÜEGG J.; CAI W.; KARIMI M.; KISS N. B.; SWEDENBORG E.; LARSSON C.; EKSTRÖM T. J, PONGRATZ I. Epigenetic regulation of glucose transporter 4 by estrogen receptor $\beta$. Mol. Endocrinol., v. 25, n. 12, p. 2017-2028, 2011.

RUSSO G. L.; VASTOLO V.; CICCARELLI M.; ALBANO L.; MACCHIA P. E.; UNGARO P. Dietary Polyphenols and Chromatin Remodelling. Crit. Rev. Food Sci. Nutr., 2015 Sep 10:0.

SALMINEN A.; KAUPPINEN A.; KAARNIRANTA K. AMPK/Snf1 signaling regulates histone acetylation: Impact on gene expression and epigenetic functions. Cell Signal., v. 28, n. 8, p. 887-895, 2016. 
SANTALUCÍA T.; MORENO H.; PALACÍN M.; YACOUB M. H.; BRAND N. J.; ZORZANO A. A novel functional co-operation between MyoD, MEF2 and TRalpha1 is sufficient for the induction of GLUT4 gene transcription. J. Mol. Biol., v. 314, n. 2, p. 195-204, 2001.

SCALBERT A.; MANACH C.; MORAND C.; RÉMÉSY C.; JIMÉNEZ L. Dietary polyphenols and the prevention of diseases. Crit. Rev. Food Sci. Nutr., v. 45, n. 4, p. 287-306, 2005.

SCALBERT A.; WILLIAMSON G. Dietary intake and bioavailability of polyphenols. J. Nutr., v. 130, p. 2073S-2085S, 2000 (Suplemento 8S).

SCHMATZ R.; SCHETINGER M. R.; SPANEVELLO R. M.; MAZZANTI C. M.; STEFANELLO N.; MALDONADO P. A.; GUTIERRES J.; CORREAA M. DE C.; GIROTTO E.; MORETTO M. B.; MORSCH V. M. Effects of resveratrol on nucleotide degrading enzymes in streptozotocin-induced diabetic rats. Life Sci., v. 84, n. 11-12, p. 345-50, 2009.

SHAHBAZIAN M. D.; GRUNSTEIN M. Functions of site-specific histone acetylation and deacetylation. Annu. Rev. Biochem., v. 76, p. 75-100, 2007.

SILAN C. The effects of chronic resveratrol treatment on vascular responsiveness of streptozotocin-induced diabetic rats. Biol. Pharm. Bull., v. 31, n. 5, p. 897-902, 2008.

SILVA J. L.; GIANNOCCO G.; FURUYA D. T.; LIMA G. A.; MORAES P. A.; NACHEF S.; BORDIN S.; BRITTO L. R.; NUNES M. T.; MACHADO U. F. NF-kappaB, MEF2A, MEF2D and HIF1-a involvement on insulin- and contraction-induced regulation of GLUT4 gene expression in soleus muscle. Mol. Cell Endocrinol., v. 240, n. 1-2, p. 82-93, 2005.

SMITH J. A.; KOHN T. A.; CHETTY A. K.; OJUKA E. O. CaMK activation during exercise is required for histone hyperacetylation and MEF2A binding at the MEF2 site on the Glut4 gene. Am. J. Physiol. Endocrinol. Metab., v. 295, n. 3, p. E698-704, 2008.

SMOLIGA J. M.; BAUR J. A.; HAUSENBLAS H. A. Resveratrol and health-a comprehensive review of human clinical trials. Mol. Nutr. Food Res., v. 55, n. 8, p. 1129-1141, 2011.

STANKOV K.; BENC D.; DRASKOVIC D. Genetic and epigenetic factors in etiology of diabetes mellitus type 1. Pediatrics., v. 132, n. 6, p. 1112-1122, 2013.

STEFAN M.; ZHANG W.; CONCEPCION E.; YI Z.; TOMER Y. DNA methylation profiles in type 1 diabetes twins point to strong epigenetic effects on etiology. J. Autoimmun., v. 50, p. 33-37, 2014.

STRAHL B. D.; ALLIS C. D. The language of covalent histone modifications. Nature., v. 403, n. 6765 , p. $41-45,2000$.

SZKUDELSKI T.; SZKUDELSKA K. Anti-diabetic effects of resveratrol. Ann. N. Y. Acad. Sci., v. 1215, p. 34-39, 2011. 
SZKUDELSKI T.; SZKUDELSKA K. Resveratrol and diabetes: from animal to human studies. Biochim. Biophys. Acta., v. 1852, n. 6, p. 1145-1154, 2015.

TAHILIANI M.; KOH K. P.; SHEN Y.; PASTOR W. A.; BANDUKWALA H.; BRUDNO Y.; AGARWAL S.; IYER L. M.; LIU D. R.; ARAVIND L.; RAO A. Conversion of 5methylcytosine to 5-hydroxymethylcytosine in mammalian DNA by MLL partner TET1. Science., v. 324, n. 5929, p. 930-935, 2009.

TAKAI D.; JONES P. A. Comprehensive analysis of CpG islands inhuman chromosomes 21 and 22. Proc. Natl. Acad. Sci., v. 99, p. 3740-3745, 2002.

TAKAOKA M. J. Of the phenolic substances of white hellebore (Veratrum grandiflorum Loes. fil.). J. Faculty Sci. Hokkaido Imperial University, v. 3, p. 1-16, 1940.

TANNO M.; SAKAMOTO J.; MIURA T.; SHIMAMOTO K.; HORIO Y. Nucleocytoplasmic shuttling of the NAD+-dependent histone deacetylase SIRT1. J. Biol. Chem., v. 282, n. 9, p. 6823-6832, 2007.

THAI M. V.; GURUSWAMY S.; CAO K. T.; PESSIN J. E.; OLSON A. L. Myocyte enhancer factor 2 (MEF2)-binding site is required for GLUT4 gene expression in transgenic mice. Regulation of MEF2 DNA binding activity in insulin-deficient diabetes. J Biol Chem., v. 73, n. 23, p. 14285-14292, 1998.

TISHINSKY J. M.; DE BOER A. A.; DYCK D. J.; ROBINSON L. E. Modulation of visceral fat adipokine secretion by dietary fatty acids and ensuing changes in skeletal muscle inflammation. Appl Physiol Nutr Metab., v. 39, n. 1, p. 28-37, 2014.

TSAO T. S.; STENBIT A. E.; FACTOR S. M.; CHEN W.; ROSSETTI L.; CHARRON M. J. Prevention of insulin resistance and diabetes in mice heterozygous for GLUT4 ablation by transgenic complementation of GLUT4 in skeletal muscle. Diabetes., v. 48, n. 4, p. 775-782, 1999.

TUNG B. T.; RODRIGUEZ-BIES E.; THANH H. N.; LE-THI-THU H.; NAVAS P.; SANCHEZ V. M.; LÓPEZ-LLUCH G. Organ and tissue-dependent effect of resveratrol and exercise on antioxidant defenses of old mice. Aging Clin. Exp. Res., v. 27, n. 6, p. 775-783, 2015.

UM J. H.; PARK S. J.; KANG H.; YANG S.; FORETZ M.; MCBURNEY M. W.; KIM M. K.; VIOLLET B.; CHUNG J. H. AMP-activated protein kinase-deficient mice are resistant to the metabolic effects of resveratrol. Diabetes., v. 59, n. 3, p. 554-563, 2010.

VAQUERO A.; SCHER M.; LEE D.; ERDJUMENT-BROMAGE H.; TEMPST P.; REINBERG D. Human SirT1 interacts with histone H1 and promotes formation of facultative heterochromatin. Mol Cell., v. 16, n. 1, p. 93-105, 2004.

VANDEN BERGHE W. Epigenetic impact of dietary polyphenols in cancer chemoprevention: lifelong remodeling of our epigenomes. Pharmacol. Res., v. 65, n. 6, p. 565-576, 2012.

VERDONE L.; CASERTA M.; DI MAURO E. Role of histone acetylation in the control of gene expression. Biochem. Cell Biol., v. 83, n. 3, p. 344-353, 2005. 
VERDONE L.; AGRICOLA E.; CASERTA M.; DI MAURO E. Histone acetylation in gene regulation. Brief Funct. Genomic Proteomic., v. 5, n. 3, p. 209-221, 2006.

VETTERLI L.; BRUN T.; GIOVANNONI L.; BOSCO D.; MAECHLER P. Resveratrol potentiates glucose-stimulated insulin secretion in INS-1E beta-cells and human islets through a SIRT1-dependent mechanism. J. Biol. Chem., v. 286, n. 8, p. 6049-6060, 2011.

VORA J.; HEISE T. Variability of glucose-lowering effect as a limiting factor in optimizing basal insulin therapy: a review. Diabetes Obes. Metab., v. 15, n. 8, p. 701-712, 2013.

YOKOMORI N.; TAWATA M.; ONAYA T. DNA demethylation during the differentiation of 3T3-L1 cells affects the expression of the mouse GLUT4 gene. Diabetes., v. 48, n. 4, p. 685690, 1999.

YONAMINE C Y.; PINHEIRO-MACHADO E.; MICHALANI M. L.; FREITAS H. S.; OKAMOTO M. M.; CORREAA-GIANNELLA M. L.; MACHADO U. F. Resveratrol improves glycemic control in insulin-treated diabetic rats: participation of the hepatic territory. Nutr Metab (Lond)., v.13, n.44, 2016.

YOUSSEF D.; EL ABBASSI A.; JORDAN R. M.; PEIRIS A. N. Fructosamine-an underutilized tool in diabetes management: case report and literature review. Tenn. Med., v. 101, n. 11, p. 31-33, 2008.

WEBER M.; HELLMANN I.; STADLER M. B.; RAMOS L.; PÄÄBO S.; REBHAN M.; SCHÜBELER D. Distribution, silencing potential and evolutionary impact of promoter DNA methylation in the human genome. Nat. Genet., v. 39, n. 4, p. 457-466, 2007.

WEYER C.; BOGARDUS C.; MOTT D. M.; PRATLEY R. E. The natural history of insulin secretory dysfunction and insulin resistance in the pathogenesis of type 2 diabetes mellitus. $\mathbf{J}$. Clin. Invest., v. 104, n. 6, p. 787-794, 1999.

WU J. M.; WANG Z. R.; HSIEH T. C.; BRUDER J. L.; ZOU J. G.; HUANG Y. Z. Mechanism of cardioprotection by resveratrol, a phenolic antioxidant present in red wine. Int $\mathbf{J}$ Mol Med., v. 8, n. 1, p. 3-17, 2001.

ZHANG T.; KRAUS W. L. SIRT1-dependent regulation of chromatin and transcription: linking $\mathrm{NAD}(+)$ metabolism and signaling to the control of cellular functions. Biochim. Biophys. Acta., v. 1804, n. 8, p. 1666-1675, 2010.

ZHANG J.; CHEN L.; ZHENG J.; ZENG T.; LI H.; XIAO H.; DENG X.; HU X. The protective effect of resveratrol on islet insulin secretion and morphology in mice on a high-fat diet. Diabetes Res. Clin. Pract., v. 97, n. 3, p. 474-482, 2012.

ZHAO Z.; HAN L. CpG islands: algorithms and applications in methylation studies. Biochem Biophys Res Commun., v. 382, n. 4, p. 643-645, 2009.

ZHENG J.; CHEN L. L.; ZHANG H. H.; HU X.; KONG W.; HU D. Resveratrol improves insulin resistance of catch-up growth by increasing mitochondrial complexes and antioxidant function in skeletal muscle. Metabolism., v. 61, n. 7, p. 954-965, 2012. 
ZHU W.; QIN W.; ZHANG K.; ROTTINGHAUS G. E.; CHEN Y. C.; KLIETHERMES B.; SAUTER E. R. Trans-resveratrol alters mammary promoter hypermethylation in women at increased risk for breast cancer. Nutr Cancer., v. 64, n. 3, p. 393-400, 2012.

ZIERATH J. R.; KROOK A.; WALLBERG-HENRIKSSON H. Insulin action and insulin resistance in human skeletal muscle. Diabetologia., v. 43, n. 7, p. 821-835, 2000.

ZORZANO A.; PALACÍN M.; GUMÀ A. Mechanisms regulating GLUT4 glucose transporter expression and glucose transport in skeletal muscle. Acta Physiol. Scand., v. 183, n. 1, p. 43$58,2005$. 